\title{
Stepwise Tfh cell differentiation revisited: new advances and long-standing questions
}

\author{
Andrew R. Schroeder ${ }^{1, \mathrm{X}} \quad$ Fangming $\mathrm{Zhu}^{1, \mathrm{X}} \quad \mathrm{Hui} \mathrm{Hu}^{{ }^{1 *}}$ \\ ${ }^{1}$ Department of Microbiology, University of Alabama at Birmingham, Birmingham, AL 35294, USA \\ ${ }^{\mathrm{x}}$ Equal contributors
}

\begin{abstract}
T follicular helper (Tfh) cells play an essential role in germinal center formation and the generation of high-affinity antibodies. Studies have proposed that Tfh cell differentiation is a multi-step process. However, it is still not fully understood how a subset of activated $\mathrm{CD}^{+} \mathrm{T}$ cells begin to express CXCR5 during the early stage of the response and, shortly after, how some CXCR5 ${ }^{+}$ precursor Tfh (pre-Tfh) cells enter B cell follicles and differentiate further into germinal center Tfh (GC-Tfh) cells while others have a different fate. In this mini-review, we summarize the recent advances surrounding these two aspects of Tfh cell differentiation and discuss related long-standing questions, including Tfh memory.
\end{abstract}

\section{Keywords}

Tfh, stepwise differentiation, germinal center, TCR, metabolism, CXCR5, transcription factor, CD4 memory

\section{Peer Review}

The peer reviewers who approve this article are:

1. Hai-Hui Xue, Center for Discovery and Innovation, Hackensack University Medical Center, Nutley, NJ, USA Competing interests: No competing interests were disclosed.

2. Joseph Craft, Department of Immunobiology, Yale University School of Medicine, New Haven, CT, USA Wenzhi Song, Department of Immunobiology, Yale University School of Medicine, New Haven, CT, USA Competing interests: No competing interests were disclosed. 
*Corresponding author: Hui Hu (huihu@uab.edu)

Competing interests: The authors declare that they have no competing interests.

Grant information: This work was supported by National Institutes of Health grant R01AI130232 (HH) and the UAB T32 GM008361 Medical Scientist Training Program (ARS).

The funders had no role in study design, data collection and analysis, decision to publish, or preparation of the manuscript.

Copyright: $\odot 2021 \mathrm{Hu} \mathrm{H}$ et al. This is an open access article distributed under the terms of the Creative Commons Attribution License, which permits unrestricted use, distribution, and reproductison in any medium, provided the original work is properly cited.

How to cite this article: Schroeder AR, Zhu F and Hu H. Stepwise Tfh cell differentiation revisited: new advances and long-standing questions. Faculty Reviews 2021 10:(3) https://doi.org/10.12703/r/10-3

Published: 15 Jan 2021, Faculty Reviews 10:(3) https://doi.org/10.12703/r/10-3 


\section{Introduction}

Upon activation, naïve $\mathrm{CD}^{+} \mathrm{T}$ cells have the potential to differentiate into distinct subsets of effector $\mathrm{T}$ helper cells with varied functions ${ }^{1}$. $\mathrm{T}$ follicular helper (Tfh) cells are a unique $\mathrm{CD}^{+} \mathrm{T}$ cell subset that provides help to B cells and is essential for germinal center (GC) formation ${ }^{2-5}$. The differentiation and function of Tfh cells have been shown to determine the kinetics and magnitude of GC B cell responses and the generation of high-affinity antibodies ${ }^{4,5}$.

Tfh cell differentiation has been proposed to be a multi-stage process ${ }^{4,6-8}$. During the early stage of $\mathrm{CD}^{+} \mathrm{T}$ cell responses, antigen presentation by dendritic cells (DCs) activates naïve $\mathrm{CD}^{+} \mathrm{T}$ cells and initiates $\mathrm{Tfh}$ cell differentiation, including the induction of CXCR5 expression?. Besides T cell receptor (TCR) signaling, co-stimulation and the local cytokine milieu are critical in Tfh fate determination ${ }^{7,10-16}$. After the DC priming stage, further Tfh cell differentiation requires interactions with B cells $7,10,17$. Intriguingly, it seems that not all of the activated $\mathrm{CXCR}^{+} \mathrm{CD}^{+} \mathrm{T}$ cells will enter $\mathrm{B}$ cell follicles and become germinal center Tfh (GC-Tfh) cells, as some activated $\mathrm{CXCR}^{+} \mathrm{CD}^{+} \mathrm{T}$ cells have been shown to develop into memory $\mathrm{CD} 4^{+} \mathrm{T}$ cells that are multi-potent ${ }^{18}$.

In the past decade, great progress has been made in our understanding of Tfh cell differentiation and function. Nonetheless, the molecular underpinning of CXCR5 induction and the signals that govern the divergence of Tfh versus non-Tfh effector cells in the early stage of $\mathrm{CD}^{+} \mathrm{T}$ cell responses are still not fully understood. In addition, with improved methods and more detailed mechanistic studies being carried out, it has become clear that the broadly defined "CXCR $5^{+}$Tfh" phenotype is too simplistic and may lead to confusion-especially regarding Tfh cell fate determination and Tfh memory. Here, we discuss recent advances in Tfh cell differentiation and highlight some important unanswered questions.

\section{DC priming for initial Tfh cell differentiation}

DCs are superior antigen-presenting cells (APCs) for naïve $\mathrm{CD}^{+} \mathrm{T}$ cell activation and differentiation ${ }^{19}$. Early studies have shown that during the initiation of the $\mathrm{CD}^{+} \mathrm{T}$ cell response, DCs were sufficient to prime naïve $\mathrm{CD} 4^{+} \mathrm{T}$ cells and generate $\mathrm{CXCR5}^{+} \mathrm{Tfh}$ cells ${ }^{9}$; however, the further differentiation into GC-Tfh cells still required B cell interactions ${ }^{7,9,10,17}$. Based on surface markers, location, and functional differences, several subsets of DCs have been identified ${ }^{20,21}$; thus, determining whether the DC subsets have different capabilities to generate Tfh responses has been an active area of research.

The two major populations of murine DCs are conventional DCs (cDCs) and plasmacytoid DCs (pDCs) ${ }^{20-22}$. The zinc finger transcription factor Zbtb46 (zDC) is selectively expressed by cDCs but not by pDCs or other myeloid cells ${ }^{23,24}$. The cDC population has been targeted by the introduction of the human diphtheria toxin receptor (DTR) into the $z D C$ gene to create zDC-DTR mice, such that zDC-expressing cDCs would be subject to diphtheria toxin (DT) treatment-mediated deletion ${ }^{23}$.
In these mice, DT treatment led to the near complete block of $\mathrm{CD}^{+}$and $\mathrm{CD}^{+}{ }^{+} \mathrm{T}$ cell activation and proliferation ${ }^{23}$. cDCs can be further classified into $\mathrm{CDC} 1 \mathrm{~s}$ and $\mathrm{cDC} 2 \mathrm{~s}$, which can be resident or migratory and have identifying surface markers that may depend on location ${ }^{20-22}$. Previous studies have shown that in the absence of migratory $\mathrm{cDC} 2 \mathrm{~s}$, resident $\mathrm{cDC} 1 \mathrm{~s}$ in lymph nodes were capable of inducing Tfh and humoral responses ${ }^{25,26}$. Recently, using Batf3 knockout (KO) mice (lacking cDC1s, with preserved $\mathrm{cDC} 2 \mathrm{~s}$ ) and Dock8 $\mathrm{KO}$ mice (preserved $\mathrm{cDC} 1 \mathrm{~s}$ but lacking cDC2s), Krishnaswamy et al. showed that the migratory $\mathrm{cDC} 2 \mathrm{~s}$, but not $\mathrm{cDC} 1 \mathrm{~s}$, uniquely induced $\mathrm{Tfh}$ cell responses at the T-B border ${ }^{27}$. This finding corroborates an earlier independent study on EBI2 function in $\mathrm{CD}_{4}^{+} \mathrm{T}$ cells ${ }^{28}$. EBI2, encoded by Gpr183, is an orphan G protein-coupled receptor that was first shown to have a critical function in the localization of activated B cells to the outer follicle and the induction of early plasmablast and antibody responses ${ }^{29,30}$. Following this, $\mathrm{Li}$ et al. found that the Tfh cell differentiation of EBI2-deficient $\mathrm{CD}^{+} \mathrm{T}$ cells was compromised in the early stage of the response in a $\mathrm{B}$ cell-independent manner $^{28}$. In EBI2-sufficient $\mathrm{CD} 4^{+} \mathrm{T}$ cells, most of the activated cells were co-localized with the activated DCIR2 $2^{+} \mathrm{cDC} 2 \mathrm{~s}$ in the outer $\mathrm{T}$ zone within 12 hours to 2 days after antigen challenge ${ }^{28}$. In the absence of EBI2, activated $\mathrm{CD}^{+} \mathrm{T}$ cells were scattered and only some were in the vicinity of DCIR2 ${ }^{+} \mathrm{CDC} 2 \mathrm{~s}^{28}$. The study went further to reveal a novel mechanism underlying this important T-DC interaction at the inter-follicular region in Tfh cell development: the activated $\mathrm{CD}^{+}{ }^{+} \mathrm{DCIR} 2^{+}$cDC2s expressed and released soluble CD25 (IL-2R $\alpha$ ) to absorb IL- $2^{28}$, thereby significantly reducing IL-2-mediated suppression of Tfh cell differentiation, as previously reported ${ }^{14,16}$.

Although cDC2s seem to play a larger role in generating Tfh responses, studies have also shown that, under certain circumstances, DCs may not be absolutely required for Tfh cell differentiation. In the study of EBI2 on T-DC interaction in Tfh cell differentiation, the deletion of $\mathrm{cDCs}$ in the $\mathrm{zDC}$ DTR mice completely abolished Tfh cell differentiation in response to SRBC-OVA immunization ${ }^{28}$. Yet using the same zDC-DTR mouse model, Arroyo et al. found that in $\mathrm{CD}^{+}$ $\mathrm{T}$ cell responses to Plasmodium, a blood-borne parasite, the CXCR5 $^{+}$Tfh cells generated in DT-treated zDC-DTR mice were at levels similar to those of wild-type mice ${ }^{31}$. Meanwhile, in the B-MHC II model in which MHC class II was expressed only on $\mathrm{CD} 19^{+} \mathrm{B}$ cells $^{31}$, $\mathrm{CXCR}^{+} \mathrm{Tfh}^{\mathrm{T}}$ cells were still generated, suggesting that B cells are sufficient to generate Tfh cells in Plasmodium infection ${ }^{31}$. Additionally, a 2015 study showed that when very high doses of antigens were used, the defective Tfh cell differentiation in the absence of DCs could be overcome as well ${ }^{32}$.

In addition to antigen delivery route and dose, antigen size can apparently have a selective impact on Tfh cell differentiation ${ }^{33}$. Another 2015 study showed that compared with an antigen size of 40 or $1000 \mathrm{~nm}$, the antigen size of about $200 \mathrm{~nm}$ induced higher Tfh cell responses and antibody responses despite a similar extent of total OT-II $\mathrm{T}$ cell responses $^{33}$. Although 
the exact mechanism is still not clear, the study provided evidence to suggest that increasing particle size (to a certain level) leads to sustained antigen presentation by DCs and maintained T-DC interactions, resulting in enhanced Tfh cell differentiation $^{33}$.

Although most studies on DCs have focused on their function to promote Tfh cell differentiation, a unique DC subset has been found to play a preferential negative role in regulating humoral responses. Kumamoto et al. showed that the CD301b DCs of migratory CD11 $b^{+}$dermal DCs expressed high levels of the PD-1 ligands 1 and 2 (PD-L1 and PD-L2), and the depletion of this DC subset resulted in enhanced Tfh, GC B cell, and antibody responses to protein antigens even in the absence of adjuvants $^{34}$.

Thus far, depending on the infectious agent, site and route of immunization, type of adjuvant, and antigen size and amount, the collected studies of various model systems suggest that almost all types of $\mathrm{cDCs}$ have the capacity to stimulate and generate $\mathrm{CXCR}^{+} \mathrm{Tfh}$ cell responses, but the $\mathrm{cDC} 2 \mathrm{~s}$ appear to play a more dominant role to inhaled antigens $\mathrm{s}^{20,21,27}$. With regard to DC priming during the initial stage of Tfh cell differentiation, one of the remaining long-standing questions goes back to the original issue of the divergence of naïve $\mathrm{CD} 4^{+} \mathrm{T}$ cells upon activation: what signals drive activated $\mathrm{CD}^{+} \mathrm{T}$ cells to become $\mathrm{CXCR}^{-}$versus $\mathrm{CXCR5}^{+}$cells? At present, the molecular mechanism underlying the induction of CXCR5 expression is still incompletely understood.

\section{CXCR5 induction}

Tfh cells were initially identified and defined as $\mathrm{CXCR} 5^{+} \mathrm{CD} 4^{+}$ $\mathrm{T}$ cells in the $\mathrm{B}$ cell follicles $\mathrm{s}^{2,3}$. Functionally, when activated $\mathrm{CD}^{+} \mathrm{T}$ cells downregulate CCR7 expression, the upregulation of CXCR5 has been shown to be involved in $\mathrm{T}$ cell migration into the B cell follicles ${ }^{35,36}$.

Studies have shown that IL-21, inducible co-stimulator (ICOS), Bcl6, and likely NFAT are important for CXCR5 expression $^{7,10,37}$, yet how to consistently induce CXCR5 expression in $\mathrm{CD}^{+} \mathrm{T}$ cells in vitro has remained a challenge ${ }^{38}$. It was remarkable when the overexpression of helix-loop-helix (HLH) transcription factor Ascl2 alone was found to be sufficient to induce CXCR5 expression in vitro and that study went further to suggest that Ascl 2 induction initiates Tfh cell programming ${ }^{39}$. Later, in another independent study on Id families and HLH E proteins, the transcription factors E12 and E47 (encoded by $T c f 3$ ) were also shown to drive CXCR5 expression in vitro $^{40}$, suggesting that HLH proteins play critical roles in regulating CXCR5 expression. Surprisingly, in the lymphocytic choriomeningitis virus (LCMV) infection model, whereas $T c f 3$ was induced in activated $\mathrm{CD}^{+} \mathrm{T}$ cells in the early days of the response, the expression of Ascl2 was not detected when CXCR5 $^{+}$Tfh cells already started to emerge ${ }^{40}$. That study on Id and E proteins went further to reveal that Id2 suppressed E12/E47 (E2A)-mediated CXCR5 upregulation in vitro, although Id2 did not seem to be able to inhibit Ascl2-medicated
CXCR5 upregulation ${ }^{40}$, suggesting that the Ascl2 expression in the later stage of Tfh cell differentiation may still be important. Interestingly, Id2 was shown to be a target of $\mathrm{Bcl} 6$, and $\mathrm{Bcl} 6$ directly repressed $\mathrm{Id} 2$ expression in $\mathrm{CD}^{+}{ }^{+} \mathrm{T}$ cells ${ }^{40}$, providing evidence of one mechanism by which Bcl6 regulates CXCR5 expression.

In the immune system, transcription factor Bach2 was first discovered as a key player in antibody class switching ${ }^{41}$. Later, in $\mathrm{T}$ cells, it was found that Bach2 is involved in $\mathrm{CD}^{+} \mathrm{T}$ cell memory and regulatory $\mathrm{T}$ (Treg) cell homeostasis ${ }^{42-45}$ and is important for restraining Th1, Th2, and Th17 cell differentiation as well ${ }^{42,46}$. Studies have also shown that Bach2 directly targets and negatively regulates Blimp $1^{44,47,48}$. Thus, it was a total surprise that the deletion of Bach2 in $\mathrm{CD}^{+} \mathrm{T}$ cells led to preferential Tfh cell differentiation ${ }^{49-51}$ despite increased Blimp1 expression and effector functions ${ }^{50,51}$. Mechanistically, Bach2 was found to be a critical early regulator of CXCR5 expression, such that enhanced Cxcr5 expression in the absence of Bach2 occurred even before the induction of Ascl2 expression ${ }^{50}$. The transcriptome analysis of naïve and activated $\mathrm{CD}^{+} \mathrm{T}$ cells showed that $T c f 3$ and $I d 2$ expression levels were not significantly affected by the absence of Bach 2 on day 3 in a protein immunization model $^{50}$, suggesting that Bach2-mediated control of CXCR5 expression is independent of and most likely prior to E2A- or Id2-mediated regulation.

In addition to a Blimp1- and E2A-dependent regulatory element in the CXCR5 intron and a Blimp1-dependent regulatory element upstream of the promoter ${ }^{52}$, a new regulatory element $36 \mathrm{~kb}$ upstream of the murine CXCR5 locus which suppresses Cxcr5 promoter activity in a Bach2-dependent manner in reporter assays in vitro was identified ${ }^{50}$. Nevertheless, despite the reporter activities, neither wild-type nor Bach2-deficient $\mathrm{CD}^{+} \mathrm{T}$ cells upregulated CXCR5 expression on the cell surface in vitro $^{50}$, suggesting that other layers are involved in the regulation of CXCR5 expression in vivo.

Although some transcription factors have been identified to promote or suppress CXCR5 expression, the upstream signaling events that control these transcription factors and lead to the induction of CXCR5 have not been well defined. In addition, whereas CXCR5 helps to define Tfh cells, some studies have shown that it may not be absolutely necessary for Tfh cell localization into the GC. An adoptive transfer study using $\mathrm{T}$ cell-deficient recipient mice $^{53}$ and a newer study using an influenza infection model in $C x c r 5^{\mathrm{f} / \mathrm{f}} \mathrm{CD} 4-\mathrm{Cre}$ mice ${ }^{54}$ showed that it was possible for CXCR5-deficient $\mathrm{CD}^{+} \mathrm{T}$ cells to enter $B$ cell follicles and form GC-Tfh cells, suggesting that some other signals allow for the GC localization of CXCR5deficient cells. Nevertheless, earlier studies demonstrating that CXCR5-deficient $\mathrm{CD}^{+} \mathrm{T}$ cells failed to enter the $\mathrm{B}$ cell follicle when adoptively transferred into CXCR5-sufficient, lympho-replete recipients ${ }^{35,36}$ indicate that CXCR5 upregulation is important in a competitive environment. More work is warranted to understand the regulation and function of CXCR5 in Tfh cell differentiation. 


\section{TCR affinity and signal strength in Tfh cell differentiation}

Using 5C.C7 (high-affinity) and 2B4 (low-affinity) PCCspecific TCR transgenic $\mathrm{T}$ cells in both co-transfer and independent adoptive transfer experiments, an early study by Fazilleau et al. found that significantly more 5C.C7 CD4 ${ }^{+} \mathrm{T}$ cells than $2 \mathrm{~B} 4 \mathrm{CD}^{+} \mathrm{T}$ cells developed into $\mathrm{CXCR}^{+} \mathrm{Tfh}$ cells, suggesting that a high-affinity TCR may lead to preferential Tfh differentiation of $\mathrm{CD}^{+}{ }^{+} \mathrm{T}$ cells ${ }^{55}$.

The link between TCR affinity and Tfh cell differentiation was further studied by tracking the progeny of adoptively transferred single naïve $\mathrm{CD}^{+} \mathrm{T}$ cells ${ }^{56}$. Tubo et al. showed that naïve $\mathrm{CD}^{+} \mathrm{T}$ cells specific to a certain peptide:MHC II underwent distinct patterns of $\mathrm{CD}^{+} \mathrm{T}$ helper cell differentiation based on unique TCRs ${ }^{56}$. As the productive TCR signal is decided not only by TCR affinity but also by the aggregate half-life of TCR:MHC interaction, the study showed that when the TCR-peptide:MHC II dwell time continued to increase, the Th1 cell differentiation would peak and decrease whereas the Tfh cell differentiation would increase and reach a plateau ${ }^{56}$. Additionally, increased doses of antigens-leading to stronger TCR signaling — seemed to favor Tfh and GC-Tfh cell development ${ }^{56,57}$.

Studies in viral infection models have shown that the IL-2/STAT5 pathway suppresses Tfh cell differentiation ${ }^{14,16}$. Using the IL-2-GFP reporter mice, both in vitro and in the ActA-deficient Listeria monocytogenes infection model in vivo, a recent study reported that within 24 hours, newly activated $\mathrm{CD}^{+} \mathrm{T}$ cells already split into two populations: IL-2 ${ }^{+}$ cells enriched for Bcl6 mRNA expression and $\mathrm{IL}_{-2}^{-} \mathrm{T}$ cells expressing higher mRNA levels of Prdml, Slprl, and Klf $2^{58}$. Then, using the IL-2-Thy1.1 reporter mice, the study showed that Thy1.1 (IL-2) expression was restricted to $\mathrm{CXCR}^{+} \mathrm{CD}^{+} \mathrm{T}$ cells and that treatment of anti-Thy 1.1 antibodies-leading to the depletion of IL-2-producing cells-abolished Tfh cell differentiation, suggesting that $\mathrm{CXCR}^{+} \mathrm{Tfh}$ cells are derived from IL-2 producers $^{58}$. The study further showed that IL-2 production and Tfh cell differentiation correlated with TCR signal strength and that higher TCR signaling favored Tfh cell development ${ }^{58}$.

Interestingly, it has also been reported that low-affinity antigen led to unimpaired Tfh cell differentiation ${ }^{59}$ and that high-affinity TCR favored Th1 over Tfh differentiation ${ }^{60}$. However, it should be noted that because TCR affinity positively correlated with cell expansion, higher-affinity TCRs led to more responding cells, including the Tfh population ${ }^{60}$. That study found that high-affinity TCR led to sustained CD25 expression and induced higher levels of TCR-regulated genes-such as Eefle1-that would promote non-Tfh effector cell differentiation in a $\mathrm{T}$ cell-intrinsic manner ${ }^{60}$.

How TCR signal strength translates into downstream transcriptional regulation that will influence the subsequent $\mathrm{T}$ cell differentiation has been a long-standing question. Recently, using the 5C.C7 TCR transgenic T cells and peptides with different binding affinities, Krishnamoorthy et al. found that the amounts of transcription factor IRF4, an immediate-early target gene of TCR signaling ${ }^{61}$, were increased proportionately to TCR signal strength ${ }^{62}$. Whereas low levels of IRF4 were critical for Tfh cell differentiation, the increased TCR signaling raised IRF4 to high levels, which in turn constrained the Tfh cell differentiation and favored the development of non-Tfh effector development ${ }^{62}$. The TCR signal strength/IRF4 level-mediated control of $\mathrm{T}$ helper cell fate was attributed to the divergent DNA motifs that the low and high levels of IRF4 target, and greater IRF4 levels allowed binding to low-affinity binding sites that were enriched in non-Tfh effector genes, and the process was independent of IL-2 signaling ${ }^{62}$.

The above studies have investigated the role of TCR affinity/ signaling in Tfh differentiation-in particular, the Tfh versus non-Tfh effector fate decision-yet it is still controversial when CXCR5 $^{-}$non-Tfh versus $\mathrm{CXCR}^{+}$Tfh divergence occurs upon naïve $\mathrm{CD}^{+}{ }^{+} \mathrm{T}$ cell activation. Studies using an LCMV model showed that this could occur as early as the second or third cell division by day 2 or 3 after infection ${ }^{7,63,64}$. Meanwhile, in a recent study using single-cell RNA sequencing to map the development of $\mathrm{CD}^{+} \mathrm{T}$ helper cell differentiation in a Plasmodium infection model, the computational analysis of a temporal mixture of Gaussian processes model (GPfates) of non-Tfh and Tfh fate bifurcation suggested that Th1 and Tfh cells start to diverge at the time point after the initial burst of cell proliferation, associated with an upregulation of aerobic glycolysis and accelerated cell cycling ${ }^{65}$. This is consistent with the findings showing that CXCR5 expression was induced in activated $\mathrm{CD}^{+} \mathrm{T}$ cells that had proliferated most ${ }^{66,67}$. It is worth pointing out that early studies using protein immunization models have reported that there is an early but transient upregulation of CXCR5 and Bcl6 proteins in activated $\mathrm{CD}^{+} \mathrm{T}$ cells $^{66,68}$. It is possible/plausible that the timing of the CXCR5non-Tfh versus $\mathrm{CXCR5}^{+} \mathrm{Tfh}$ divergence varies in response to different antigens/infections. Nevertheless, the sustained increase of Bcl6 expression eventually marks the differentiation of Tfh cells, consistent with the role of Bcl6 as the central regulator of $\mathrm{Tfh}$ cell differentiation ${ }^{69-71}$. The regulation of $\mathrm{Bcl} 6$ expression in activated $\mathrm{CD}^{+}{ }^{+} \mathrm{T}$ cells, however, is still under intense investigation.

New factors that regulate Bcl6 and Tfh differentiation Many transcription factors have been discovered to play important roles in Tfh cell development ${ }^{10,15,16,37,39,62,69,72-84}$. Adding to this, a number of new factors to regulate Bcl6 expression and function as well as Tfh cell differentiation have recently been identified.

\section{TCF1/LEF-1}

TCF1 (encoded by Tcf7) and LEF1 (encoded by Lef1) are transcription factors containing a conserved high-mobility-group DNA-binding domain and have been shown to be important for early $\mathrm{T}$ cell development and memory $\mathrm{CD}^{+} \mathrm{T}$ cells ${ }^{85-89}$. TCF1 has also been reported to be involved in Th2 cell differentiation and IL-17A production ${ }^{90,91}$. In naïve $\mathrm{CD}^{+} \mathrm{T}$ cells, both TCF1 and LEF1 are expressed at high levels ${ }^{92}$. Three 2015 studies showed that the deletion of TCF1 or LEF1 (or both) resulted 
in impaired Tfh cell differentiation ${ }^{63,92,93}$. In the LCMV infection model, within 3 days of infection, it was found that the activated $\mathrm{CD}^{+}{ }^{+} \mathrm{T}$ cells had already divided into $\mathrm{TCF} 1^{+} \mathrm{Blimp} 1^{-/ \mathrm{lo}}$ versus $\mathrm{TCF} 1^{-/ / \mathrm{B}} \mathrm{Blimp} 1^{+}$populations and that the $\mathrm{TCF}^{+}$population later differentiated into $\mathrm{Tfh}$ cells ${ }^{63}$. In addition, there seemed to be an antagonistic network between the IL-2/Blimp1 axis and TCF1: IL-2 signaling and Blimp1 suppressed TCF1 expression and favored Th1 effector cell differentiation, while TCF1 negatively regulated CD25 and Blimp1 expression, promoting Tfh cell differentiation ${ }^{63}$. TCF1 has also been shown to negatively modulate the expression levels of Th1 regulators T-bet and $\mathrm{Id} 2$ in a Blimp1-dependent manner ${ }^{94}$. In addition, TCF1 has multiple isoforms due to differential promoter usage and alternative splicing ${ }^{95}$. It was discovered that TCF1 long isoforms (p45 and p42) containing an N-terminal $\beta$-catenin-binding domain were required for Tfh cell differentiation and memory Tfh cells ${ }^{95}$ and that TCF1 and Blimp1 were mutual direct targets ${ }^{63,94}$. In the LCMV model, TCF1 was also found to bind a large number of Tfh genes, including Il6st and (in particular) $B c l 6^{92,93}$. Loss of TCF1 also resulted in reduced cell proliferation and increased apoptosis ${ }^{92,93}$.

An intriguing point of the TCF1 function is that it seems the role of TCF1 in Tfh cell differentiation may be specific to immune responses against viral infections ${ }^{63,92,93}$. It was mentioned that in a protein immunization model, the Tfh cell development was TCF1-independent ${ }^{63}$. In agreement with this observation, almost no CD25 expression was detected in activated CD4 ${ }^{+}$ $\mathrm{T}$ cells in NP-OVA antigen challenge in vivo (F.M. Zhu and $\mathrm{H}$. Hu, unpublished data). It is conceivable that the regulatory mechanisms of $\mathrm{Tfh}$ cell differentiation vary in cells responding to different types of infections/challenges and this possibility warrants more investigation.

\section{Ezh2 and Nsd2}

The histone methyltransferase (HMT) Ezh2 catalyzes H3K27 trimethylation and has been shown to play important roles in Th1, Th2, and Treg cells via its HMT activity ${ }^{96-100}$. Recently, a study by $\mathrm{Li}$ et al. unveiled novel and unexpected mechanisms by which Ezh2 regulates $\mathrm{Tfh}$ cell differentiation ${ }^{101}$. Ezh2-deficient $\mathrm{CD}^{+} \mathrm{T}$ cells were activated at a frequency similar to that of wild-type $\mathrm{CD} 4^{+} \mathrm{T}$ cells ${ }^{101}$. However, the deletion of Ezh2 resulted in severely defective Tfh cell development ${ }^{101}$. Ezh2 interacts with DNA only in coordination with binding partners; for this reason, the authors combined transcription factor and histone ChIP-seq (chromatin immunoprecipitation followed by sequencing) analysis and gene set enrichment analysis and found that almost half of the Ezh2 binding peaks overlapped with TCF1 peaks ${ }^{101}$. These two transcription factors activated a common subset of target genes in the Tfh cell program, with $70 \%$ of Ezh2/TCF1 co-occupied regions located in the gene promoters ${ }^{101}$. More detailed analyses showed that Ezh2, in its Ser21 phosphorylated form, cooperated with TCF1 and directly regulated $\mathrm{Bcl} 6$ expression $^{101}$. In Tfh cells, surprisingly, Ezh2 was found to be associated with more H3K27ac and active gene transcription than $\mathrm{H} 3 \mathrm{~K} 27 \mathrm{me} 3$ and gene repression ${ }^{101}$. Yet Ezh2 HMT activity is still important, as Ezh2 repressed p19Arf, an alternative splicing product of Cdkn2a, to promote $\mathrm{Tfh}$ cell survival ${ }^{101}$. Another interesting discovery was that p19Arf was found to directly interact with and antagonize Bcl6 function ${ }^{101}$. Thus, in Tfh cell differentiation, Ezh2 not only helps increase the Bcl6 expression but also prevents p19Arf from antagonizing the Bc16 function, revealing a multifaceted role for Ezh2 in Tfh differentiation ${ }^{101}$.

In a parallel study, Chen et al. also discovered and emphasized that Ezh2 is important for the early commitment of Tfh cells ${ }^{64}$. The study combined ATAC-seq (assay for transposaseaccessible chromatin using sequencing) and histone ChIP-seq to demonstrate that in the LCMV model, in which Th1 and Tfh cell differentiation programs started to diverge as early as day 2 after infection, Ezh2 was critical for the remodeling of chromatin accessibility of a cluster of Tfh-associated genes, including the Bcl6 locus in particular ${ }^{64}$.

Another HMT, Nsd2, has also been reported to play an important role in $\mathrm{Tfh}$ cell differentiation. Induced by $\mathrm{CD} 28$ stimulation, the H3K36me2 methyltransferase Nsd2 has been shown to be required for increased Bcl6 expression as early as the first cell division ${ }^{102}$. The increased Nsd2 expression after $\mathrm{T}$ cell activation was further sustained by ICOS signaling and this was important for the maintenance of Tfh cells ${ }^{102}$.

\section{Tox proteins}

The HMG box transcription factor Tox is involved in $\mathrm{CD}^{+}$ $\mathrm{T}$ cell development in the thymus, natural killer cell differentiation, and lymph node organogenesis ${ }^{103}$. Recently, this transcription factor received a lot of attention after its essential role in exhausted $\mathrm{CD}^{+} \mathrm{T}$ cell programming was revealed ${ }^{104-108}$. As a key molecular regulator of exhausted $\mathrm{CD}^{+} \mathrm{T}$ cell development, Tox was shown to recruit diverse chromatin remodeling factors to modulate chromatin accessibility and epigenetic changes, thereby regulating a network of transcription factors and their targets ${ }^{105,108}$. On the other hand, in $\mathrm{CD}^{+} \mathrm{T}$ cells in vitro, under Tfh-like conditions, a recent study showed that Tox2 proteins regulated the Tfh-associated transcriptional program by promoting chromatin remodeling and cooperative function with IL-6 signaling and the Tfh transcription factors Bcl6, Ascl2, and Batf ${ }^{109}$. That study further revealed that Bcl6 directly regulated Tox 2 and that Tox 2 inhibited Th1, Th2, and Th17 cell differentiation ${ }^{109}$. Interestingly, the study also showed that Tox and Tox 2 shared many overlapping functions in Tfh cell differentiation and that the two transcription factors synergized in regulating $\mathrm{T}$ cell localization in $\mathrm{GCs}^{109}$.

\section{Thpok}

Studies have shown that, during thymocyte development, Thpok is a $\mathrm{CD}^{+} \mathrm{T}$ cell lineage-specific transcription factor that promotes $\mathrm{CD}^{+} \mathrm{T}$ cell differentiation ${ }^{110,111}$. In an activation-induced deletion model, a recent study showed that Thpok was not required for $\mathrm{CD}^{+} \mathrm{T}$ cell expansion but was critical for $\mathrm{Tfh}$ cell differentiation and the subsequent GC $\mathrm{B}$ cell responses ${ }^{112}$. That study showed that Thpok acted upstream of Bcl6 and directly regulated $\mathrm{Bcl} 6$ expression, yet $\mathrm{Bcl} 6$ overexpression alone was not sufficient to rescue the defective Tfh cell development in the absence of Thpok ${ }^{112}$. A more detailed analysis showed that Thpok was responsible for establishing the Tfh cell transcriptome using a mechanism independent of the interference 
from Blimp1 or Runx3, controlling many genes important for Tfh function which are not regulated by Bcl6 (for example, $\left(d 40(g)^{112}\right.$. Finally, the rescue experiments revealed that Maf, together with Bcl6, helped restore Tfh cell differentiation ${ }^{112}$.

\section{Extracellular matrix protein 1}

Extracellular matrix protein 1 (ECM1) is a secreted protein and its mutations can lead to the genetic disorder lipoid proteinosis $^{113}$. In $\mathrm{CD}^{+} \mathrm{T}$ cells, ECM1 has been shown to regulate Th2 cell migration and Th17 cell differentiation ${ }^{114,115}$. Recently, He et al. found that Ecml was expressed at much higher levels in Tfh cells than in non-Tfh cells and the cytokines IL-6 and IL-21 enhanced ECM1 expression in activated $\mathrm{CD}^{+} \mathrm{T}$ cells at both mRNA and protein levels ${ }^{116}$. The binding of STAT3 to the promoter and the first intron region of the Ecml locus suggested that Ecml is a direct target of STAT3 ${ }^{116}$. The study also nicely demonstrated that ECM1 promoted Tfh cell differentiation in an autocrine manner ${ }^{116}$. Mechanistically, ECM1 functioned to preserve Bcl6 expression by antagonizing the IL-2-STAT5 signaling pathway ${ }^{116}$.

\section{Prkd2}

$\operatorname{Prkd} 2$ is one of the three serine/threonine protein kinase D family isoforms that have been indicated to regulate cytokine production in activated $\mathrm{T}$ cells ${ }^{117}$. In a forward genetic screen, a missense mutation of Prkd2 and subsequently the generation of mice carrying this mutation or deficient in Prkd2 were all found to exhibit excessive antibody responses ${ }^{118}$. More in-depth analyses showed that the excessive GC B cell development and the increased serum $\operatorname{IgE}, \operatorname{IgG} 1$, and $\operatorname{IgA}$ levels in Prkd2-deficient mice were Tfh-dependent ${ }^{118}$. Mechanistically, it was found that Prkd2 directly bound to $\mathrm{Bcl} 6$ and induced phosphorylation of $\mathrm{Bcl} 6$, which restricted $\mathrm{Bcl} 6$ nuclear translocation in $\mathrm{CD}^{+}{ }^{+} \mathrm{T}$ cells ${ }^{118}$. The loss of Prkd2 resulted in increased Bcl6 amounts in nuclear fractions, thereby enhancing Tfh cell development. Interestingly, Bcl6 was shown to downregulate Prkd2 expression in $\mathrm{CD}^{+}{ }^{+} \mathrm{T}$ cells ${ }^{118}$, forming a mutual inhibitory-positive feedback system that facilitates $\mathrm{Tfh}$ cell differentiation.

Despite the new advances in our understanding of the transcriptional program controlling $\mathrm{Tfh}$ cell differentiationincluding the new players upstream of Bcl6-the question of Tfh fate determination still appears to be complicated. In particular, it seems that not all of the $\mathrm{CXCR}^{+}$precursor Tfh (pre-Tfh) will enter B cell follicles and become GC-Tfh cells ${ }^{18,31}$. In this regard, the question remains as to which $\mathrm{CXCR}^{+} \mathrm{Bcl6}^{+} \mathrm{CD} 4^{+}$ pre-Tfh cells will become GC-Tfh cells and which ones will have different fates.

\section{Tfh cell migration and position}

For $\mathrm{CXCR}^{+}$pre-Tfh cells to enter B cell follicles and become GC-Tfh cells, cell migration is a crucial part of the process. Early studies have shown that SAP-mediated regulation of T-B interactions and ICOS-ICOSL-mediated cell motility are necessary for $\mathrm{CXCR}^{+}$pre-Tfh cells to enter B cell follicles and help form $\mathrm{GCs}^{7,10,119,120}$. ICOS stimulates PI3K signaling, and using a novel mouse model with a gain-of-function point mutation of the PI3K subunit $110 \delta$ (PI3K $\delta$ ), Preite et al. found that the mutant $\mathrm{PI} 3 \mathrm{~K} \delta$ was able to induce enhanced Tfh cell differentiation in an ICOS-independent manner ${ }^{121}$, consistent with an earlier study showing that the constitutively active form of PI3K subunit $\mathrm{p} 110 \alpha$ was also sufficient to increase Tfh cell responses $^{122}$. Interestingly, it seems that PI3K signaling is also used by PD-1, via interaction with bystander B cells expressing PD-L1, to regulate Tfh cell position in $\mathrm{GCs}^{123}$. Shi et al. showed that in vitro, PD-1 suppressed PI3K activation triggered by CXCR5, and in vivo, PD-1 antagonized ICOS and suppressed the follicle recruitment of Tfh cells ${ }^{123}$. Meanwhile, the PD-1 engagement promoted Tfh cell concentration in the GC by limiting CXCR3-mediated distraction ${ }^{123}$.

Following the idea that a contact-based mechanism may be critical for Tfh cell trafficking and retention in GCs, Lu et al. screened the erythropoietin-producing hepatocellular receptor $(\mathrm{EPH})$ and $\mathrm{EPH}-$ interacting protein (ephrin, EFN) family ${ }^{124}$. They found that the deficiency of EFNB1, a class B ephrin highly expressed in GC B cells, and the knockdown of EPHB6, a class B EPH receptor induced in Tfh cells and bound by EFNB1, both resulted in exaggerated GC Tfh retention ${ }^{124}$. Although EFNB1 did not seem to affect the overall GC B cell responses, its deficiency impacted the plasma cell formation, particularly the bone marrow plasma cell compartment ${ }^{124}$. They also found that EFNB1 and EPHB4 were necessary for IL-21 production by Tfh cells ${ }^{124}$.

Another interesting pair of contact-dependent adhesive guidance receptors for $\mathrm{Tfh}$ cells in GC responses are Plexin B2 (PlxnB2) and Sema4C ${ }^{125}$. Similar to EFNB1 and EPHBs, PlxnB2 was uniquely expressed on GC B cells whereas Sema4C was specifically expressed on Tfh cells ${ }^{125}$. Yan et al. showed that in PlxnB2-deficient GCs, the Tfh cells were concentrated along the edge of the $\mathrm{GC}^{125}$. The disruption of PlxnB2-Sema4C interactions interfered with the directional guidance of $\mathrm{Tfh}$ cells deep into the GC and reduced antibody affinity maturation and generation of plasma cells ${ }^{125}$.

A separate study showed that $\alpha_{\mathrm{V}}$ integrin was also essential for the accumulation of Tfh cells in the $\mathrm{GC}^{126}$. The study found that $\alpha_{\mathrm{v}}$ integrin was not required for $\mathrm{Tfh}$ cell differentiation or provision of help to B cells; rather, $\alpha_{\mathrm{v}}$ integrin was important for Tfh accumulation in $\mathrm{GCs}^{126}$. Although early antibody responses were normal, the deletion of $\alpha_{\mathrm{v}}$ integrin resulted in reduced number and size of GCs at later time points of the response to protein immunization, and the generation of long-lived antibody-producing cells in influenza virus infection model was compromised ${ }^{126}$. Interestingly, in the absence of $\alpha_{\mathrm{v}}$ integrin, the generation of memory $\mathrm{B}$ cells seemed to be intact ${ }^{126}$, consistent with a study showing that memory B cells are generated in earlier waves than plasma cells during the GC responses $^{127}$.

\section{Tfh cell metabolism}

$\mathrm{T}$ cell activation and differentiation are accompanied by dynamic metabolic re-programming ${ }^{128,129}$. The mechanistic target of rapamycin (mTOR) is a serine/threonine kinase that senses and 
integrates multiple signals to regulate cell growth, proliferation, differentiation, metabolism, and survival ${ }^{130,131}$. Interacting with scaffold proteins Raptor and Rictor, mTOR forms two distinct complexes-mTORC1 and mTORC2, respectively-that have different sensitivities to rapamycin as well as upstream signals and downstream functions ${ }^{130,131}$.

An early study by Ray et al. on mTOR signaling in Tfh cells showed that in the LCMV model, compared with Th1 cells, Tfh cells were less proliferative and had less metabolic function, including less glycolysis and mitochondrial metabolism ${ }^{132}$. Using a short hairpin RNA (shRNA) knockdown approach, the authors showed that mTOR silencing in activated SMARTA $\mathrm{T}$ cells led to reduced Th1 cell differentiation but did not affect Bcl6 expression or Tfh cell differentiation ${ }^{132}$. In the LCMV model, previous studies have shown that activated Blimp $1^{+} \mathrm{CD} 4^{+}$ $\mathrm{T}$ cells expressed high levels of $\mathrm{CD} 25^{63}$. Combined with the results that $\mathrm{Tfh}$ cells had reduced Akt and mTOR signaling compared with Th1 cells in vivo and that overexpression of constitutively active Akt promoted Th1 cell differentiation, that study suggests that in addition to the IL-2/STAT5/Blimp1 axis, the IL-2/Akt/mTOR axis also favors Th1 cell development at the expense of Tfh cells ${ }^{132}$.

However, three independent studies using Raptor- and Rictorconditional KO mouse lines reached a different conclusion. (1) Zeng et al. showed that ICOS stimulation activated mTORC1 and mTORC2 and promoted glucose uptake, glycolysis, and lipogenesis for $\mathrm{Tfh}$ cell differentiation ${ }^{122}$. Interestingly, mTORC1 and mTORC2 induced discrete programs, in which mTORC2 regulated the activation and translocation of Foxo $1^{122}$, an important transcription factor that has been shown to be important for $\mathrm{Tfh}$ cell development ${ }^{80}$. (2) Yang et al. showed that whereas mTORC1-deficient $\mathrm{CD}^{+}{ }^{+} \mathrm{T}$ cells were severely defective in cell proliferation and $\mathrm{Tfh}$ cell differentiation ${ }^{67}$, mTORC2-mediated control of Tfh cell differentiation was partially attributed to its regulation of Akt activation and TCF1/Bcl6 axis ${ }^{67}$. (3) Hao et al. confirmed that TCR and ICOS stimulation activated mTORC2 signaling and that mTORC2 was important for $\mathrm{Tfh}$ cell differentiation after the early stage of the $\mathrm{CD}^{+} \mathrm{T}$ cell response ${ }^{133}$. Additionally, the study found that mTORC2 deficiency led to impaired cell migration and $\mathrm{B}$ cell help function ${ }^{133}$. Although there were a few discrepancies among these three studies-regarding cell proliferation/ survival, Bcl6 and TCF1 expression levels, and so on ${ }^{67,122,133}$ - the collective results were in agreement that both mTORC1 and mTORC2 intrinsically promoted Tfh cell development.

The opposite conclusions on the role of mTOR signaling in Tfh cell differentiation may stem from the experimental approaches used: Ray et al. took the shRNA knockdown approach in activated $\mathrm{CD}^{+} \mathrm{T}$ cells ${ }^{132}$, whereas the other three groups studied genetic deletion in naïve $\mathrm{CD}^{+} \mathrm{T}$ cells ${ }^{67,122,133}$. Interestingly, the published data regarding $\mathrm{Tfh}$ cell proliferation have also drawn opposite conclusions: some studies found that Tfh cells were less proliferative than Th1 cells ${ }^{132}$, whereas other studies reported that $\mathrm{Bcl}^{\mathrm{hi}}$ cells had higher proliferation and higher levels of cell cycle-related gene expression ${ }^{58,134,135}$.
Upon further analysis, however, all these discrepancies are pointing to a more fundamental issue that needs to be addressed in the Tfh field: in combination with timeline, can we identify more cell surface markers or new means to distinguish the various stages of Tfh cell differentiation and the subsets of Tfh cells?

In most of the literature, CXCR5 expression has become an easy surrogate of Tfh cell differentiation. As mentioned above, studies have shown that CXCR5 expression was induced as early as the second or third cell division after infection ${ }^{7,63,64}$ or in activated $\mathrm{CD}^{+} \mathrm{T}$ cells that had proliferated most ${ }^{66,67}$. Meanwhile, a single-cell RNA sequencing analysis also suggests that the Th1 versus Tfh divergence occurs at a time point after the initial burst of cell proliferation ${ }^{65}$. Such early activated CXCR5 $5^{+}$"pre-Tfh" cells would appear to be highly proliferative. $\mathrm{CXCR}^{+}$pre-Tfh cells need to enter B cell follicles and become CXCR5 $5^{\text {hi }}$ GC-Tfh cells to form GC responses ${ }^{7,17,136}$. There is evidence that after the early activation and expansion stage but before the full formation of the GC, CXCR5 ${ }^{+}$ pre-Tfh cells have already reduced cell proliferation; that is, they are less proliferative ${ }^{134}$ (F.M. Zhu and H. Hu, unpublished data). Although many studies do not separate $\mathrm{CXCR}^{+}$ pre-Tfh cells from CXCR5 ${ }^{\text {hi }}$ GC-Tfh cells in their analyses, most CXCR5 $^{\text {hi }}$ GC-Tfh cells have been shown to be in a nonproliferative $\operatorname{state}^{136}$ (F.M. Zhu and H. Hu, unpublished data). The overexpression of Bcl6 resulted in the reduction of glucose metabolism of activated CD4 ${ }^{+} \mathrm{T}$ cells ${ }^{137}$. A separate study suggests that $\mathrm{Bcl} 6$ protein synthesis is also controlled by mTOR signaling ${ }^{138}$. Thus, it is conceivable that whereas PI3K-mTOR signaling supports the activation of $\mathrm{CD}^{+} \mathrm{T}$ cells and the differentiation of early-stage pre-Tfh cells (the highly proliferative ones) via TCF1- and Foxo1-mediated regulation, the progressively increased Bcl6 expression may reprogram the Tfh cells into a different metabolic state afterwards. Taken together, these studies indicate that mTOR signaling and metabolic requirements likely differ between the stages of Tfh cell differentiation. Thus, a more accurate understanding of the stepwise Tfh cell differentiation and the identification of stage-specific markers remain important pursuits in the Tfh field.

It has been reported that the microenvironment in GCs is hypoxic, and hypoxia-inducible factors (HIFs) have been shown to be critical for GC B cell responses ${ }^{139}$. In $\mathrm{CD}^{+}{ }^{+} \mathrm{T}$ cells upon activation, Cho et al. showed that both HIF-1 $\alpha$ and HIF- $2 \alpha$ expression levels were regulated by mTORC1 and mTORC2 signaling and that the deletion of HIF-1 $\alpha$ alone or both HIF- $1 \alpha$ and HIF-2 $\alpha$ led to the reduced generation of Tfh cells and an increased ratio of $\mathrm{T}$ follicular regulatory (Tfr) cells to Tfh cells $^{140}$. Furthermore, HIF-regulated cytokines and cytokinemediated metabolism influenced the function of $\mathrm{Tfh}$ cells providing help to B cells ${ }^{140}$.

Hypoxia-adenosinergic immunosuppression refers to the suppression of activated immune cells by hypoxia-driven accumulation of extracellular adenosine via cell surface A2 adenosine receptors ${ }^{141}$. The potential hypoxic environment in the GC led to the examination of the A2a adenosine receptor 
(A2aR) in Tfh cells, and indeed the deletion of $\mathrm{A} 2 \mathrm{aR}$ in $\mathrm{CD}^{+} \mathrm{T}$ cells resulted in increased $\mathrm{Tfh}$ cell differentiation ${ }^{142}$. Similarly, as dephosphorylation of extracellular ATP generates extracellular adenosine ${ }^{143}$, ATP-gated ionotropic P2X7 receptor (P2RX7) has also been studied in Tfh responses ${ }^{144}$. Expressed at high levels in Tfh cells, P2RX7 has been found to mediate Tfh cell death and limit GC responses in Peyer's patches ${ }^{144}$.

\section{Tfh cell number}

A key feature of the GC B cell response is affinity maturation $^{145}$. Using an innovative $\alpha \mathrm{DEC}$ model system in which OVA antigen was delivered directly to GC B cells, Victora et al. showed that with increased opportunity to present antigens to Tfh cells and receive Tfh cell help, GC B cells had less competition with each other, leading to a decrease in the number of high-affinity $\mathrm{B}$ cells ${ }^{146}$. The study suggested that $\mathrm{T}$ cell help is a limiting factor for affinity maturation ${ }^{146}$. These observations have raised intriguing questions of whether Tfh cell number is a limiting factor and how the manipulation of the number of Tfh cells-and thereby the help provided by these cells-may shape the GC responses and affinity selection.

Previous studies have shown that deletion of transcription factor Foxp1 leads to dramatically enhanced Tfh cell responses, GC B cell responses, and the production of antibodies, including high-affinity antibodies ${ }^{79}$. A recent mechanistic study revealed that part of the Foxp1-mediated regulation of Tfh cell differentiation is through CTLA-4: CTLA-4 is a direct target of Foxp1, CTLA-4 expression levels were decreased in the absence of Foxp1, and overexpression of CTLA-4 suppressed Tfh cell differentiation $^{68}$. Deleting Foxp1 in $\mathrm{CD}^{+}{ }^{+} \mathrm{T}$ cells or blocking CTLA-4 led to increased numbers of Tfh cells, and both situations resulted in increased GC B cell numbers and selection of high-affinity B cells as well as abolished intra-clonal B cell competition $^{68}$, as high numbers of single-clone B cells have been shown to result in intra-clonal $\mathrm{B}$ cell competition and reduced affinity maturation ${ }^{147}$. Other studies have also shown that increasing or decreasing the number of Tfh cells-through genetic manipulation or chemical intervention-increases or decreases the GC B cell responses accordingly ${ }^{92,148-150}$.

To summarize, the help provided by Tfh cells during Tfh-GC B interaction is a limiting resource during the selection process in the GC; meanwhile, the collective results support the notion that increased Tfh numbers lead to stronger GC responses, resulting in more GC B cells, increased BCR affinity, and higher antibody titer. So far none of the existing model systems have separated a change in Tfh cell number from Tfh cell function. Manipulating Tfh cell number and function will continue to be important topics for studies of the GC response and vaccine development/vaccination strategies.

\section{Tfh subsets}

Studies have shown that during GC responses, activated GC $B$ cells have multiple fates ${ }^{145}$. This observation naturally leads to an intriguing question of whether there are different Tfh subsets with varied functions to help B cells. IL-21 and IL-4 are two well-recognized cytokines produced by Tfh cells providing help to $\mathrm{B}$ cells $\mathrm{s}^{10,11,151-155}$. Using IL-21 and IL-4 dual-reporter mice in a subcutaneous helminth infection model, Weinstein et al. showed that these two important cytokines were produced in a progressive manner by $\mathrm{Tfh}$ cells ${ }^{156}$. IL-21 was generated first in the early time points of the response, followed by IL-4 production and a substantial number of double-positive cells ${ }^{156}$. At the later stage, IL-21 production was gradually lost but IL-4 expression was sustained ${ }^{156}$. The cytokine-based Tfh subsets-termed Tfh 21 , Tfh $21+4$, and Tfh 4 cells-were found to have different transcriptome profiling, and Tfh21 and Tfh4 localized differently in the $\mathrm{GC}^{156}$. The three groups of $\mathrm{Tfh}$ cells also displayed distinct functions in helping B cells: Tfh21 cells seemed to assist more in promoting high-affinity selection whereas Tfh $21+4$ and Tfh4 cells facilitated the generation of plasma cells ${ }^{156}$

Besides Tfh21, Tfh21+4, and Tfh4 cells, Gowthaman et al. recently identified an IL-13-producing Tfh subset (Tfh13) that drives the production of high-affinity $\operatorname{IgE}$ antibodies ${ }^{157}$. Previously, it was shown that IL-4 production in Tfh cells is independent of $\mathrm{Gata}^{158}$ - an essential transcription factor for IL-4 production in Th2 cells ${ }^{159}$. While studying a hyper-IgE phenotype associated with Dock8 deficiency, Gowthaman et al. found that a subset of Dock8-deficient Tfh cells expressed high levels of IL-4, IL-5, and IL-13 but low levels of IL-21 ${ }^{157}$. This unique Tfh13 subset was also induced in wild-type mice during allergic sensitization to multiple allergens but not in a murine helminth infection model of Th2 responses ${ }^{157}$. More importantly, Tfh13 cells were also detected in the peripheral blood of patients with a peanut allergy ${ }^{157}$. In an independent study of a house dust mite sensitization model, IL-13-producing Tfh cells were also observed ${ }^{160}$.

In the $\mathrm{CD}^{+} \mathrm{T}$ cell responses to Zika virus (ZIKV), a preferential Th1-like Tfh cell response has been observed ${ }^{161}$. The robust interferon gamma (IFN $\gamma$ )-producing Tfh cells were induced by replicable ZIKV infection, and the Th1-like Tfh cell differentiation was $\mathrm{T}$-bet-dependent ${ }^{161}$. IFN $\gamma$-producing $\mathrm{Tfh}$ cells were also found in responses to LCMV infection ${ }^{162-164}$. Interestingly, depending on the environment setting, T-bet actually plays diversified roles in $\mathrm{Tfh}$ cell differentiation and function. In the $\mathrm{CD}^{+}{ }^{+} \mathrm{T}$ cell responses to influenza infection, Sheikh et al . showed that the loss of T-bet promoted Tfh cell differentiation at the expense of Th1 cells ${ }^{163}$. Supporting this, in a Salmonella infection model, Elsner et al. showed that the Salmonella infection induced IL-12 production, which in turn induced high levels of T-bet that favored Th1 cell differentiation and suppressed Tfh cell differentiation ${ }^{165}$. In LCMV infection, however, under $\mathrm{T}$ cell competition conditions, the loss of T-bet resulted in a deficiency of both Th1 and Tfh cell responses ${ }^{162,163}$. For Th1-like Tfh cells, using a T-bet fate-mapping mouse strain, Fang et al. reported that the IFN $\gamma$-producing GC-Tfh subset had a history of T-bet expression ${ }^{166}$. Within the GC-Tfh cell population, all the cells capable of IFN $\gamma$ production were from this Th1-like Tfh subset; the Ifng locus was found to be partially accessible only in such cells, and the early stage of T-bet expression was essential $^{166}$.

Regarding IL-2 production by Tfh cells, Papillion et al. recently showed that GC-Tfh cells secreted large amounts of IL- ${ }^{167}$. The study went further to link the compromised late Tfh cell 
responses in the absence of IL-6 to IL-2 responsiveness of GC-Tfh cells, such that IL-6 signaling restrained the suppressive function of IL-2 on GC-Tfh cells by reducing CD122 expression $^{167}$.

It is very interesting that the cytokine profiles of Tfh cells seem to be in accord with the infection to which they are responding, and these subsets may localize differently within the GC microanatomy and help B cells differently. Further understanding of the underlying mechanism will generate new opportunities for the fine tuning of the GC response in the treatment of diseases or in prophylactic vaccines.

\section{Tfh memory}

The recall responses of $\mathrm{CXCR}^{+} \mathrm{CD} 4^{+}$memory $\mathrm{T}$ cells in various model systems appear to be quite different. Studies in protein vaccination and LCMV infection models have shown that $\mathrm{CXCR}^{+} \mathrm{CD}^{+}{ }^{+} \mathrm{Tfh}$ memory cells form after the primary $\mathrm{CD} 4^{+}$ $\mathrm{T}$ cell responses, and they preferentially give rise to $\mathrm{Tfh}$ recall responses $^{168,169}$. Recently, it was reported that both local and circulating Tfh memory cells function in helping the secondary humoral responses in mice ${ }^{170}$. On the other hand, in a Listeria monocytogenes infection model, Pepper et al. showed that the $\mathrm{CXCR}^{+} \mathrm{CD}^{+}$memory $\mathrm{T}$ cells adopted a central memory $\mathrm{T}$ cell phenotype as they expressed CCR7 and were located mainly in $\mathrm{T}$ cell areas after transfer ${ }^{18}$. Upon re-challenge, $\mathrm{CXCR}^{+} \mathrm{CD}^{+}$memory $\mathrm{T}$ cells were less potent in IFN $\gamma$ production compared with Th1 effector memory $\mathrm{T}$ cells, but they rapidly produced IL-2 and generated a diverse secondary response, including robust non-Tfh responses ${ }^{18}$. In this regard, the mixed/diverse recall responses of $\mathrm{CXCR} 5^{+} \mathrm{CD} 4^{+}$memory $\mathrm{T}$ cells suggest multi-potency or plasticity.

Recently, in addition to having an important role in $\mathrm{Tfh}$ cell differentiation ${ }^{112}$, the transcription factor Thpok has been found to be critical for central memory $\mathrm{CD}^{+} \mathrm{T}$ cells ${ }^{171}$. Using single-cell RNA sequencing, Ciucci et al. identified a unique gene expression signature that excludes typical Tfh and Th1 effector genes but contains genes linked to memory potential ${ }^{171}$. These $\mathrm{CD}^{+}{ }^{+} \mathrm{T}$ cells expressed CXCR5 and CCR7 and were designated $\mathrm{T}$ central memory precursors ${ }^{171}$. Thpok-deficient CD $4^{+}$ $\mathrm{T}$ cells in the memory stage exhibited lower levels of Cxcr5, Ccr7, Tcf7, Bcl2, and Il7R; mechanistically, Thpok was found to be essential for the generation and functional fitness of memory precursors by directly repressing Prdm1 and Runx3 expression $^{171}$.

After naïve $\mathrm{CD}^{+} \mathrm{T}$ cells are activated, presumably not all the newly generated $\mathrm{CXCR}^{+} \mathrm{CD} 4^{+} \mathrm{T}$ cells at the $\mathrm{T}-\mathrm{B}$ border will enter B cell follicles and become GC-Tfh cells. The studies mentioned above raise the question of which $\mathrm{CXCR} 5^{+} \mathrm{CD} 4^{+}$ $\mathrm{T}$ cells would differentiate into PD- $1^{\text {hi }} \mathrm{CXCR} 5^{\text {hi }}$ GC-Tfh cells versus $\mathrm{CXCR} 5^{+} \mathrm{CD} 4$ " "central" memory T cells.

$\mathrm{CXCR}^{+} \mathrm{CD}^{+}$memory $\mathrm{T}$ cells have been shown to be multi-potent ${ }^{18}$. By blocking cell death induced by
NAD-mediated ribosylation of $\mathrm{P} 2 \mathrm{RX} 7$ during isolation from tissues, in the LCMV infection model, Kunzli et al. showed that long-lived Tfh cells retained plasticity ${ }^{172}$. In their study, compared with day 15 GC-Tfh cells, the long-lived (>400 days) Tfh cells expressed PD-1 and CXCR5 at levels resembling $\mathrm{CXCR}^{+} \mathrm{CD}^{+}$memory $\mathrm{T}$ cells ${ }^{172}$. It has been suggested that when GC response was fading, PD- $1{ }^{\text {hi }} \mathrm{CXCR} 5^{\text {hi }}$ GC-Tfh cells downregulated Bcl6 and CXCR5 expression levels ${ }^{134,136}$. Thus, whereas the $\mathrm{CXCR} 5^{+} \mathrm{CD} 4^{+}$memory $\mathrm{T}$ cell population as a whole can give rise to both non-Tfh and Tfh responses ${ }^{18}$, it is unclear whether this is due to the plasticity of these cells or because $\mathrm{CXCR}^{+} \mathrm{CD}^{+}$memory cells represent a heterogeneous population of bona fide GC-Tfh memory cells mixed with less differentiated "central plastic" memory cells. The differences and relationship between $\mathrm{CXCR} 5^{+} \mathrm{CD} 4^{+} \mathrm{CCR} 7^{-}$preTfh cells, CXCR5 ${ }^{+} \mathrm{CD} 4^{+} \mathrm{CCR} 7^{+}$"central" memory precursors, and $\mathrm{CXCR}^{\text {hi }}$ GC-Tfh cells are still under-studied and remain important issues that need to be addressed.

\section{Concluding remarks}

Tfh cells are essential for GC B cell responses and antibody affinity maturation. As most of the successful vaccines function by inducing protective antibody responses to T-dependent antigens, the differentiation and function of $\mathrm{Tfh}$ cells will continue to be crucial topics in vaccine design. Recently, a study in non-human primates demonstrated that low-dose immunizations over prolonged intervals led to enhanced antibody responses to HIV antigens, and part of the mechanism was an increase in Tfh cells targeting a broader set of epitopes ${ }^{173}$. That study provides one example of continued efforts to generate novel vaccines and the crucial role played by Tfh cells in the process. Additionally, Tfh cells have been shown to be associated with a broad range of autoimmune diseases ${ }^{5,38}$, suggesting that discoveries in this field will have wide-reaching implications.

There are many other new and exciting findings regarding $\mathrm{Tfh}$ and $\mathrm{GC}$ responses-including $\mathrm{Tfr}$ cells, follicular cytotoxic $\mathrm{T}$ (Tfc) cells, miRNA regulation of Tfh cells, the human Tfh studies, and Tfh cells in diseases-that due to space constraints could not be included in this limited review. Questions remain regarding our understanding of the mechanism of Tfh cell differentiation, Tfh subsets, memory, and regulation of Tfh function. Future studies will help us take advantage of this unique population of helper $\mathrm{CD}^{+}$cells for vaccine development and the treatment of diseases.

\section{Abbreviations}

A2aR, A2a adenosine receptor; APC, antigen-presenting cell; $\mathrm{cDC}$, conventional dendritic cell; $\mathrm{cDC} 1$, type 1 conventional dendritic cell; cDC2, type 2 conventional dendritic cell; DC, dendritic cell; DT, diphtheria toxin; EFN, EPH-interacting protein; EPH, erythropoietin-producing hepatocellular receptor; GC, germinal center; GC-Tfh, germinal center Tfh; HLH, helix-loop-helix; HMT, histone methyltransferase; KO, knockout; mTOR, mechanistic target of rapamycin; P2RX7, ATP-gated 
ionotropic $\mathrm{P} 2 \mathrm{X} 7$ receptor; $\mathrm{pDC}$, plasmacytoid dendritic cell;

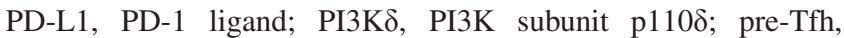
precursor Tfh; TCR, T-cell receptor; Tfc, T follicular cytotoxic; $\mathrm{Tfh}, \mathrm{T}$ follicular helper; Tfh13, IL-13-producing Tfh; Tfr, T follicular regulatory; zDC, transcription factor Zbtb46
Authors' contributions

ARS and FZ contributed to the review and editing of the manuscript. $\mathrm{HH}$ contributed to the preparation of the original draft and to the review and editing of the manuscript.
1. Zhu J, Yamane H, Paul WE: Differentiation of effector CD4 T cell populations (*). Annu Rev Immunol. 2010; 28: 445-89. PubMed Abstract | Publisher Full Text | Free Full Text

2. Breitfeld D, Ohl L, Kremmer E, et al:: Follicular B helper $\mathbf{T}$ cells express $\mathbf{C X C}$ chemokine receptor $\mathbf{5}$, localize to $\mathrm{B}$ cell follicles, and support immunoglobulin production. J Exp Med. 2000; 192(11): 1545-52. PubMed Abstract | Publisher Full Text | Free Full Text

3. Schaerli $\mathrm{P}$, Willimann $\mathrm{K}$, Lang $\mathrm{AB}$, et al.: CXC chemokine receptor $\mathbf{5}$ expression defines follicular homing T cells with B cell helper function. J Exp Med. 2000; 192(11): 1553-62.

PubMed Abstract | Publisher Full Text | Free Full Text

4. Crotty S: Follicular helper CD4 T cells (TFH). Annu Rev Immunol. 2011; 29: 621-63

PubMed Abstract | Publisher Full Text

5. Vinuesa CG, Linterman MA, Di Yu, et al.: Follicular Helper T Cells. Annu Rev Immunol. 2016; 34: 335-68. PubMed Abstract | Publisher Full Text

6. Cannons JL, Qi H, Lu KT, et al.: Optimal germinal center responses require a multistage $T$ cell: $B$ cell adhesion process involving integrins, SLAMassociated protein, and CD84. Immunity. 2010; 32(2): 253-65. PubMed Abstract | Publisher Full Text | Free Full Text | Faculty Opinions Recommendation

7. Choi YS, Kageyama R, Eto D, et al.: ICOS receptor instructs $T$ follicular helper cell versus effector cell differentiation via induction of the transcriptional repressor Bcl6. Immunity. 2011; 34(6): 932-46. PubMed Abstract | Publisher Full Text | Free Full Text | Faculty Opinions Recommendation

8. Kerfoot SM, Yaari G, Patel JR, et al:: Germinal center B cell and T follicular helper cell development initiates in the interfollicular zone. Immunity. 2011; 34(6): 947-60.

PubMed Abstract | Publisher Full Text | Free Full Text |

Faculty Opinions Recommendation

9. Goenka R, Barnett LG, Silver JS, et al.: Cutting edge: Dendritic cell-restricted antigen presentation initiates the follicular helper $T$ cell program but cannot complete ultimate effector differentiation. $J$ Immunol. 2011; 187(3): 1091-5. PubMed Abstract | Publisher Full Text | Free Full Tex

10. Nurieva RI, Chung Y, Hwang D, et al.: Generation of T follicular helper cells is mediated by interleukin-21 but independent of $T$ helper 1,2 , or 17 cell lineages. Immunity. 2008; 29(1): 138-49. PubMed Abstract | Publisher Full Text | Free Full Text | Faculty Opinions Recommendation

11. Vogelzang A, McGuire $\mathrm{HM}, \mathrm{Di}$ Yu, et al:: A fundamental role for interleukin-21 in the generation of $T$ follicular helper cells. Immunity. 2008; 29(1): 127-37. PubMed Abstract | Publisher Full Text

12. Ma CS, Suryani S, Avery DT, et al.: Early commitment of naïve human CD4(+) T cells to the $\mathrm{T}$ follicular helper (T(FH)) cell lineage is induced by IL-12. Immunol Cell Biol. 2009; 87(8): 590-600.

PubMed Abstract | Publisher Full Text

13. Schmitt N, Morita R, Bourdery L, et al.: Human dendritic cells induce the differentiation of interleukin-21-producing $\mathrm{T}$ follicular helper-like cells through interleukin-12. Immunity. 2009; 31(1): 158-69. PubMed Abstract | Publisher Full Text | Free Full Text | Faculty Opinions Recommendation

14. Ballesteros-Tato A, León B, Graf BA, et al: Interleukin-2 inhibits germinal center formation by limiting $\mathrm{T}$ follicular helper cell differentiation. Immunity. 2012; 36(5): 847-56.

PubMed Abstract | Publisher Full Text | Free Full Text | Faculty Opinions Recommendation

15. Choi YS, Eto D, Yang JA, et al:: Cutting edge: STAT1 is required for IL-6mediated Bcl6 induction for early follicular helper cell differentiation.
J Immunol. 2013; 190(7): 3049-53. PubMed Abstract | Publisher Full Text | Free Full Text

16. Johnston RJ, Choi YS, Diamond JA, et al:: STAT5 is a potent negative regulator of TFH cell differentiation. J Exp Med. 2012; 209(2): 243-50. PubMed Abstract | Publisher Full Text | Free Full Text | Faculty Opinions Recommendation

17. $\mathrm{Xu} \mathrm{H}, \mathrm{Li} \mathrm{X}, \mathrm{Liu} \mathrm{D}$, et al.: Follicular T-helper cell recruitment governed by bystander B cells and ICOS-driven motility. Nature. 2013; 496(7446): 523-7. PubMed Abstract | Publisher Full Text | Faculty Opinions Recommendation

18. Pepper M, Pagán AJ, Igyártó BZ, et al:: Opposing signals from the Bcl6 transcription factor and the interleukin-2 receptor generate T helper 1 central and effector memory cells. Immunity. 2011; 35(4): 583-95. PubMed Abstract | Publisher Full Text | Free Full Text | Faculty Opinions Recommendation

19. Banchereau J, Briere F, Caux C, et al:: Immunobiology of dendritic cells. Annu Rev Immunol. 2000; 18: 767-811. PubMed Abstract | Publisher Full Text

20. Eisenbarth SC: Dendritic cell subsets in T cell programming: Location dictates function. Nat Rev Immunol. 2019; 19(2): 89-103. PubMed Abstract | Publisher Full Text

21. Krishnaswamy JK, Alsén S, Yrlid U, et al.: Determination of T Follicular Helper Cell Fate by Dendritic Cells. Front Immunol. 2018; 9: 2169. PubMed Abstract | Publisher Full Text | Free Full Text

22. Schlitzer A, Zhang $\mathrm{W}$, Song $\mathrm{M}$, et al:: Recent advances in understanding dendritic cell development, classification, and phenotype [version 1; peer review: 2 approved]. F1000Res. 2018; 7: F1000 Faculty Rev-1558. PubMed Abstract | Publisher Full Text | Free Full Text | Faculty Opinions Recommendation

23. Meredith MM, Liu K, Darrasse-Jeze G, et al: Expression of the zinc finger transcription factor zDC (Zbtb46, Btbd4) defines the classical dendritic cell transcription factor ZDC (Zbtb46, Btbd4) lineage. J Exp Med. 2012; 209(6): 1153-65.
PubMed Abstract | Publisher Full Text | Free Full Text Faculty Opinions Recommendation

24. Satpathy AT, KC W, Albring JC, et al:: Zbtb46 expression distinguishes classical dendritic cells and their committed progenitors from other immune lineages. J Exp Med. 2012; 209(6): 1135-52. PubMed Abstract | Publisher Full Text | Free Full Text | Faculty Opinions Recommendation

25. Woodruff MC, Heesters BA, Herndon $\mathrm{CN}$, et al:: Trans-nodal migration of resident dendritic cells into medullary interfollicular regions initiates immunity to influenza vaccine. J Exp Med. 2014; 211(8): 1611-21. PubMed Abstract | Publisher Full Text | Free Full Text | Faculty Opinions Recommendation

26. Gerner MY Torabi-Parizi P, Germain RN, et al:: Strategically localized dendritic cells promote rapid $\mathrm{T}$ cell responses to lymph-borne particulate antigens. Immunity. 2015; 42(1): 172-85. PubMed Abstract | Publisher Full Text | Faculty Opinions Recommendation

27. Krishnaswamy JK, Gowthaman U, Zhang B, et al:: Migratory CD11b+ conventional dendritic cells induce $\mathrm{T}$ follicular helper cell-dependent antibody responses. Sci Immunol. 2017; 2(18): eaam9169. PubMed Abstract | Publisher Full Text | Faculty Opinions Recommendation

28. $\mathrm{Li} \mathrm{J}, \mathrm{Lu} \mathrm{E}, \mathrm{Yi}$ T, et al.: EBI2 augments Tfh cell fate by promoting interaction with IL-2-quenching dendritic cells. Nature. 2016; 533(7601): 110-4 PubMed Abstract | Publisher Full Text | Free Full Text | Faculty Opinions Recommendation

29. Pereira JP, Kelly LM, Xu Y, Cyster JG, et al.: EBI2 mediates B cell segregation between the outer and centre follicle. Nature. 2009; 460(7259): 
$1122-6$

PubMed Abstract | Publisher Full Text | Free Full Text |

Faculty Opinions Recommendation

30. Gatto D, Paus D, Basten A, et al:: Guidance of B cells by the orphan G proteincoupled receptor EBI2 shapes humoral immune responses. Immunity. 2009; 31(2): 259-69.

PubMed Abstract | Publisher Full Text

31. Arroyo EN, Pepper M: B cells are sufficient to prime the dominant CD4+ Tfh response to Plasmodium infection. J Exp Med. 2020; 217(2): e20190849. PubMed Abstract | Publisher Full Text | Free Full Text

32. Dahlgren MW, Gustafsson-Hedberg T, Livingston M, et al:: $T$ follicular helper, but not Th1, cell differentiation in the absence of conventional dendritic cells. $J$ Immunol. 2015; 194(11): 5187-99.

PubMed Abstract | Publisher Full Text

33. Benson RA, MacLeod MKL, Hale BG, et al.: Antigen presentation kinetics control $\mathrm{T}$ cell/dendritic cell interactions and follicular helper $\mathrm{T}$ cell generation in vivo. Elife. 2015; 4: e06994.

PubMed Abstract | Publisher Full Text | Free Full Text

34. Kumamoto $\mathrm{Y}$, Hirai T, Wong PW, et al:: CD301 b+ dendritic cells suppress $\mathrm{T}$ follicular helper cells and antibody responses to protein antigens. Elife. 2016; 5: e17979.

PubMed Abstract | Publisher Full Text | Free Full Text

35. Hardtke S, Ohl L, Förster R, et al.: Balanced expression of CXCR5 and CCR7 on follicular $\mathrm{T}$ helper cells determines their transient positioning to lymph node follicles and is essential for efficient B-cell help. Blood. 2005; 106(6): 1924-31. PubMed Abstract | Publisher Full Text

36. Haynes NM, Allen CDC, Lesley R, et al:: Role of CXCR5 and CCR7 in follicular Th cell positioning and appearance of a programmed cell death gene-1high germinal center-associated subpopulation. J Immunol. 2007; 179(8): 5099-108. PubMed Abstract | Publisher Full Text

37. Martinez GJ, Hu JK, Pereira RM, et al.: Cutting Edge: NFAT Transcription Factors Promote the Generation of Follicular Helper T Cells in Response to Acute Viral Infection. J Immunol. 2016; 196(5): 2015-9.

PubMed Abstract | Publisher Full Text | Free Full Text

38. Crotty S: T follicular helper cell differentiation, function, and roles in disease. Immunity. 2014; 41(4): 529-42.

PubMed Abstract | Publisher Full Text | Free Full Text

39. L Liu X, Chen X, Zhong B, et al: Transcription factor achaete-scute homologue 2 initiates follicular T-helper-cell development. Nature. 2014; 507(7493): 513-8.

PubMed Abstract | Publisher Full Text | Free Full Text |

Faculty Opinions Recommendation

40. Shaw LA, Bélanger S, Omilusik KD, et al: Id2 reinforces TH1 differentiation and inhibits E2A to repress TFH differentiation. Nat Immunol. 2016; 17(7): 834-43. PubMed Abstract | Publisher Full Text | Free Full Text

41. Muto A, Tashiro S, Nakajima O, et al:: The transcriptional programme of antibody class switching involves the repressor Bach2. Nature. 2004; 429(6991): 566-71.

PubMed Abstract | Publisher Full Text

42. Roychoudhuri R, Hirahara K, Mousavi K, et al.: BACH2 represses effector programs to stabilize $\mathrm{T}_{\text {reg }}$-mediated immune homeostasis. Nature. 2013; 498(7455): 506-10.

PubMed Abstract | Publisher Full Text | Free Full Text |

Faculty Opinions Recommendation

43. Kim EH, Gasper DJ, Lee SH, et al:: Bach2 regulates homeostasis of Foxp3 regulatory $\mathrm{T}$ cells and protects against fatal lung disease in mice. $J$ Immunol. 2014; 192(3): 985-95.

PubMed Abstract | Publisher Full Text | Free Full Text

44. Tsukumo S-i, Unno M, Muto A, et al.: Bach2 maintains T cells in a naive state by suppressing effector memory-related genes. Proc Natl Acad Sci U S A. 2013; 110(26): 10735-40.

PubMed Abstract | Publisher Full Text | Free Full Text

45. Roychoudhuri R, Clever D, Li P, et al.: BACH2 regulates CD8(+) T cell differentiation by controlling access of AP-1 factors to enhancers. Nat Immunol. 2016; 17(7): 851-60.

PubMed Abstract | Publisher Full Text | Free Full Text

46. Kuwahara M, Ise W, Ochi M, et al:: Bach2-Batf interactions control Th2-type immune response by regulating the IL-4 amplification loop. Nat Commun. 2016; 7: 12596.

PubMed Abstract | Publisher Full Text | Free Full Text

47. Ochiai K, Katoh $\mathrm{Y}$, Ikura T, et al.: Plasmacytic transcription factor Blimp-1 is repressed by Bach2 in B cells. J Biol Chem. 2006; 281(50): 38226-34. PubMed Abstract | Publisher Full Text

48. Ochiai $\mathrm{K}$, Muto $\mathrm{A}$, Tanaka $\mathrm{H}$, et al:: Regulation of the plasma cell transcription factor Blimp-1 gene by Bach2 and Bcl6. Int Immunol. 2008; 20(3): 453-60. PubMed Abstract | Publisher Full Text

49. Lahmann A, Kuhrau J, Fuhrmann F, et al:: Bach2 Controls T Follicular Helper Cells by Direct Repression of Bcl-6. J Immunol. 2019; 202(8): 2229-39. PubMed Abstract | Publisher Full Text

50. Geng J, Wei H, Shi B, et al:: Bach2 Negatively Regulates T Follicular Helper Cell Differentiation and Is Critical for CD4+ T Cell Memory. J Immunol. 2019; 202(10): 2991-8.

PubMed Abstract | Publisher Full Text | Free Full Text
51. Zhang $\mathrm{H}, \mathrm{Hu} \mathrm{Q}$, Zhang M, et al.: Bach2 Deficiency Leads to Spontaneous Expansion of IL-4-Producing T Follicular Helper Cells and Autoimmunity. Front Immunol. 2019; 10: 2050.

PubMed Abstract | Publisher Full Text | Free Full Text

52. Leong YA, Chen Y, Ong HS, et al:: CXCR5(+) follicular cytotoxic T cells control viral infection in B cell follicles. Nat Immunol. 2016; 17(10): 1187-96. PubMed Abstract | Publisher Full Text | Faculty Opinions Recommendation

53. Arnold CN, Campbell DJ, Lipp M, et al.: The germinal center response is impaired in the absence of T cell-expressed CXCR5. Eur J Immunol. 2007; 37(1): $100-9$.

PubMed Abstract | Publisher Full Text

54. Vanderleyden I, Fra-Bido SC, Innocentin S, et al.: Follicular Regulatory T Cells Can Access the Germinal Center Independently of CXCR5. Cell Rep. 2020; 30(3): 611-619.e4

PubMed Abstract | Publisher Full Text | Free Full Text

55. Fazilleau N, McHeyzer-Williams LJ, Rosen $\mathrm{H}$, et al:: The function of follicular helper $\mathrm{T}$ cells is regulated by the strength of $\mathrm{T}$ cell antigen receptor binding Nat Immunol. 2009; 10(4): 375-84.

PubMed Abstract | Publisher Full Text | Free Full Text

56. Tubo NJ, Pagán AJ, Taylor JJ, et al:: Single naive $\mathrm{CD}^{+}{ }^{+} \mathrm{T}$ cells from a diverse repertoire produce different effector cell types during infection. Cell. 2013; 153(4): 785-96.

PubMed Abstract | Publisher Full Text | Free Full Text

Faculty Opinions Recommendation

57. Baumjohann D, Preite S, Reboldi A, et al:: Persistent antigen and germinal center $\mathrm{B}$ cells sustain $\mathrm{T}$ follicular helper cell responses and phenotype. Immunity. 2013; 38(3): 596-605.

PubMed Abstract | Publisher Full Text | Faculty Opinions Recommendation

58. DiToro D, Winstead CJ, Pham D, et al.: Differential IL-2 expression defines developmental fates of follicular versus nonfollicular helper T cells. Science. 2018; 361(6407): eaao2933.

PubMed Abstract | Publisher Full Text | Free Full Text |

Faculty Opinions Recommendation

59. Keck S, Schmaler M, Ganter S, et al.: Antigen affinity and antigen dose exert distinct influences on CD4 T-cell differentiation. Proc Natl Acad Sci U S A. 2014; distinct influences

PubMed Abstract | Publisher Full Text | Free Full Text |

Faculty Opinions Recommendation

60. Kotov DI, Mitchell JS, Pengo T, et al.: TCR Affinity Biases Th Cell Differentiation by Regulating CD25, Eef1e1, and Gbp2. J Immunol. 2019; 202(9): 2535-45. PubMed Abstract | Publisher Full Text | Free Full Text

61. Matsuyama T, Grossman A, Mittrücker HW, et al:: Molecular cloning of LSIRF, a lymphoid-specific member of the interferon regulatory factor family that binds the interferon-stimulated response element (ISRE). Nucleic Acids Res. 1995; 23(12): 2127-36.

PubMed Abstract | Publisher Full Text | Free Full Text

62. Krishnamoorthy V, Kannanganat S, Maienschein-Cline M, et al: : The IRF4 Gene Regulatory Module Functions as a Read-Write Integrator to Dynamically Coordinate T Helper Cell Fate. Immunity. 2017; 47(3): 481-497.e7. PubMed Abstract | Publisher Full Text | Free Full Text

63. Wu T, Shin HM, Moseman EA, et al.: TCF1 Is Required for the T Follicular Helper Cell Response to Viral Infection. Cell Rep. 2015; 12(12): 2099-110. PubMed Abstract | Publisher Full Text | Free Full Text

64. Chen X, Cao G, Wu J, et al.: The histone methyltransferase EZH2 primes the early differentiation of follicular helper T cells during acute viral infection. Cell Mol Immunol. 2020; 17(3): 247-60.

PubMed Abstract | Publisher Full Text | Free Full Text

65. Lönnberg T, Svensson V, James KR, et al.: Single-cell RNA-seq and computational analysis using temporal mixture modelling resolves Th1/Tfh fate bifurcation in malaria. Sci Immunol. 2017; 2(9): eaal2192. PubMed Abstract | Publisher Full Text | Free Full Text

66. Baumjohann D, Okada T, Ansel KM: Cutting Edge: Distinct waves of BCL6 expression during $T$ follicular helper cell development. J Immunol. 2011; 187(5): 2089-92.

PubMed Abstract | Publisher Full Text | Faculty Opinions Recommendation

67. Yang J, Lin X, Pan Y, et al:: Critical roles of mTOR Complex 1 and 2 for $T$ follicular helper cell differentiation and germinal center responses. eLife. 2016; 5: e17936.

PubMed Abstract | Publisher Full Text | Free Full Text

68. Shi B, Geng J, Wang YH, et al.: Foxp1 Negatively Regulates T Follicular Helpe Cell Differentiation and Germinal Center Responses by Controlling Cell Migration and CTLA-4. J Immunol. 2018; 200(2): 586-94. PubMed Abstract | Publisher Full Text | Free Full Text

69. Johnston RJ, Poholek AC, DiToro D, et al.: Bcl6 and Blimp-1 are reciprocal and antagonistic regulators of $\mathrm{T}$ follicular helper cell differentiation. Science. 2009; 325(5943): 1006-10.

PubMed Abstract | Publisher Full Text | Free Full Text |

Faculty Opinions Recommendation

70. Nurieva RI, Chung Y, Martinez GJ, et al.: Bcl6 mediates the development of $\mathrm{T}$ follicular helper cells. Science. 2009; 325(5943): 1001-5. PubMed Abstract | Publisher Full Text | Free Full Text 
71. Di Yu, Rao S, Tsai LM, et al.: The transcriptional repressor Bcl-6 directs T follicular helper cell lineage commitment. Immunity. 2009; 31(3): 457-68. PubMed Abstract | Publisher Full Text | Faculty Opinions Recommendation

72. Betz BC, Jordan-Williams KL, Wang C, et al:: Batf coordinates multiple aspects of $\mathrm{B}$ and $\mathrm{T}$ cell function required for normal antibody responses. $J$ Exp Med. 2010; 207(5): 933-42.

PubMed Abstract | Publisher Full Text | Free Full Text

73. Bauquet AT, Jin H, Paterson AM, et al.: The costimulatory molecule ICOS regulates the expression of C-Maf and IL-21 in the development of follicular T helper cells and TH-17 cells. Nat Immunol. 2009; 10(2): 167-75. PubMed Abstract | Publisher Full Text | Free Full Text | Faculty Opinions Recommendation

74. Kwon $\mathrm{H}$, Thierry-Mieg D, Thierry-Mieg J, et al:: Analysis of interleukin-21-induced Prdm1 gene regulation reveals functional cooperation of STAT3 and IRF4 transcription factors. Immunity. 2009; 31(6): 941-52. PubMed Abstract | Publisher Full Text | Free Full Text

75. Ise W, Kohyama M, Schraml BU, et al:: The transcription factor BATF controls the global regulators of class-switch recombination in both $\mathrm{B}$ cells and T cells. Nat Immunol. 2011; 12(6): 536-43.

PubMed Abstract | Publisher Full Text | Free Full Text |

Faculty Opinions Recommendation

76. Bollig N, Brüstle A, Kellner K, et al:: Transcription factor IRF4 determines germinal center formation through follicular T-helper cell differentiation. Proc Natl Acad Sci U S A. 2012; 109(22): 8664-9.

PubMed Abstract | Publisher Full Text | Free Full Text

77. Auderset F, Schuster S, Fasnacht N, et al:: Notch signaling regulates follicula helper T cell differentiation. J Immunol. 2013; 191(5): 2344-50. PubMed Abstract | Publisher Full Text

78. Omodho B, Miao T, Symonds ALJ, et al:: Transcription factors early growth response gene (Egr) 2 and 3 control inflammatory responses of tolerant $T$ cells. Immun Inflamm Dis. 2018; 6(2): 221-33.

PubMed Abstract | Publisher Full Text | Free Full Text

79. Wang $\mathrm{H}$, Geng J, Wen $\mathrm{X}$, et al:: The transcription factor Foxp1 is a critical negative regulator of the differentiation of follicular helper T cells. Nat Immunol. 2014; 15(7): 667-75.

PubMed Abstract | Publisher Full Text | Free Full Text

80. Stone EL, Pepper M, Katayama CD, et al.: ICOS coreceptor signaling inactivates the transcription factor FOXO1 to promote Tfh cell differentiation. Immunity. 2015; 42(2): 239-51.

PubMed Abstract | Publisher Full Text | Free Full Text

81. Lee JY, Skon CN, Lee YJ, et al.: The transcription factor KLF2 restrains CD4 $^{+} \mathrm{T}$ follicular helper cell differentiation. Immunity. 2015; 42(2): 252-64. PubMed Abstract | Publisher Full Text | Free Full Text | Faculty Opinions Recommendation

82. Weber JP, Fuhrmann F, Feist RK, et al.: ICOS maintains the T follicular helpe cell phenotype by down-regulating Krüppel-like factor 2. J Exp Med. 2015; 212(2): 217-33.

PubMed Abstract | Publisher Full Text | Free Full Text

83. Stauss D, Brunner C, Berberich-Siebelt $F$, et al:: The transcriptional coactivator Bob1 promotes the development of follicular T helper cells via Bcl6. EMBO J. 2016; 35(8): 881-98.

PubMed Abstract | Publisher Full Text | Free Full Text

84. Serre K, Mohr E, Bénézech C, et al:: Selective effects of NF-кB1 deficiency in CD4 ${ }^{+} \mathrm{T}$ cells on Th2 and TFh induction by alum-precipitated protein vaccines. Eur J Immunol. 2011; 41(6): 1573-82. PubMed Abstract | Publisher Full Text

85. Weber BN, Chi AWS, Chavez A, et al.: A critical role for TCF-1 in T-lineage specification and differentiation. Nature. 2011; 476(7358): 63-8. PubMed Abstract | Publisher Full Text | Free Full Text | Faculty Opinions Recommendation

86. CYu S, Zhou X, Steinke FC, et al.: The TCF-1 and LEF-1 transcription factors have cooperative and opposing roles in $\mathrm{T}$ cell development and malignancy. Immunity. 2012; 37(5): 813-26.

PubMed Abstract | Publisher Full Text | Free Full Text |

Faculty Opinions Recommendation

87. Steinke FC, Yu S, Zhou X, et al.: TCF-1 and LEF-1 act upstream of Th-POK to promote the CD4(+) T cell fate and interact with Runx3 to silence Cd4 in CD8(+) T cells. Nat Immunol. 2014; 15(7): 646-56. PubMed Abstract | Publisher Full Text | Free Full Text

88. Jeannet G, Boudousquié C, Gardiol N, et al:: Essential role of the Wnt pathway effector Tcf-1 for the establishment of functional CD8 T cell memory Proc Natl Acad Sci U S A. 2010; 107(21): 9777-82. PubMed Abstract | Publisher Full Text | Free Full Text I Faculty Opinions Recommendation

89. Zhou X, Yu S, Zhao DM, et al.: Differentiation and persistence of memory CD8(+) T cells depend on T cell factor 1. Immunity. 2010; 33(2): 229-40. PubMed Abstract | Publisher Full Text | Free Full Text | Faculty Opinions Recommendation

90. Yu Q, Sharma A, Oh SY, et al.: T cell factor $\mathbf{1}$ initiates the $\mathbf{T}$ helper type $\mathbf{2}$ fate by inducing the transcription factor GATA-3 and repressing interferon-gamma.

Nat Immunol. 2009; 10(9): 992-9.

PubMed Abstract | Publisher Full Text | Free Full Text

91. Yu Q, Sharma A, Ghosh A, et al.: T cell factor-1 negatively regulates expression of IL-17 family of cytokines and protects mice from experimental autoimmune encephalomyelitis. J Immunol. 2011; 186(7): 3946-52.

PubMed Abstract | Publisher Full Text | Free Full Text

92. Choi YS, Gullicksrud JA, Xing S, et al:: LEF-1 and TCF-1 orchestrate T(FH) differentiation by regulating differentiation circuits upstream of the transcriptional repressor Bcl6. Nat Immunol. 2015; 16(9): 980-90. PubMed Abstract | Publisher Full Text | Free Full Text

93. Xu L, Cao Y, Xie Z, et al.: The transcription factor TCF-1 initiates the differentiation of $\mathbf{T}(\mathrm{FH})$ cells during acute viral infection. Nat Immunol. 2015 16(9): 991-9.

PubMed Abstract | Publisher Full Text

94. Shao P, Li F, Wang J, et al.: Cutting Edge: Tcf1 Instructs T Follicular Helper Cell Differentiation by Repressing Blimp1 in Response to Acute Viral Infection. $J$ Immunol. 2019; 203(4): 801-6.

PubMed Abstract | Publisher Full Text | Free Full Text

95. Gullicksrud JA, Li F, Xing S, et al.: Differential Requirements for Tcf1 Long Isoforms in $\mathrm{CD}^{+}$and $\mathrm{CD4}^{+} \mathrm{T}$ Cell Responses to Acute Viral Infection. $J$ Immunol. 2017; 199(3): 911-9.

PubMed Abstract | Publisher Full Text | Free Full Text

96. Koyanagi M, Baguet A, Martens J: EZH2 and histone $\mathbf{3}$ trimethyl lysine $\mathbf{2 7}$ associated with II4 and II13 gene silencing in $\mathrm{T}_{\mathrm{h}} \mathbf{1}$ cells. J Biol Chem. 2005; 280(36): 31470-7.

PubMed Abstract | Publisher Full Text

97. Tumes DJ, Onodera A, Suzuki A, et al:: The polycomb protein Ezh2 regulates differentiation and plasticity of CD4(+) T helper type 1 and type 2 cells. Immunity. 2013; 39(5): 819-32.

PubMed Abstract | Publisher Full Text | Faculty Opinions Recommendation

98. Arvey A, van der Veeken J, Samstein RM: Inflammation-induced repression of chromatin bound by the transcription factor Foxp3 in regulatory T cells. Nat Immunol. 2014; 15(6): 580-7.

PubMed Abstract | Publisher Full Text | Free Full Text |

Faculty Opinions Recommendation

99. DuPage M, Chopra G, Quiros J, et al:: The chromatin-modifying enzyme Ezh2 is critical for the maintenance of regulatory $\mathrm{T}$ cell identity after activation. Immunity. 2015; 42(2): 227-38.

PubMed Abstract | Publisher Full Text | Free Full Text |

Faculty Opinions Recommendation

100. Yang XP, Jiang K, Hirahara $\mathrm{K}$, et al.: EZH2 is crucial for both differentiation of regulatory T cells and T effector cell expansion. Sci Rep. 2015; 5: 10643. PubMed Abstract | Publisher Full Text | Free Full Text

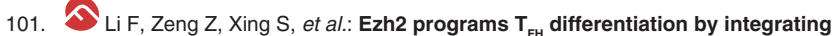
phosphorylation-dependent activation of $\mathrm{Bcl} 6$ and polycomb-dependent repression of p19Arf. Nat Commun. 2018; 9(1): 5452 PubMed Abstract | Publisher Full Text | Free Full Text Faculty Opinions Recommendation

102. Long $X$, Zhang $L$, Zhang $Y$, et al:: Histone methyltransferase Nsd2 is required for follicular helper T cell differentiation. J Exp Med. 2020; 217(1): e20190832. PubMed Abstract | Publisher Full Text | Free Full Text

103. Aliahmad $P$, Seksenyan $A$, Kaye J: The many roles of TOX in the immune system. Curr Opin Immunol. 2012; 24(2): 173-7. PubMed Abstract | Publisher Full Text | Free Full Text

104. Seo H, Chen J, González-Avalos E, et al.: TOX and TOX2 transcription factors cooperate with NR4A transcription factors to impose $\mathrm{CD}^{+} \mathrm{T}$ cell exhaustion. Proc Natl Acad Sci U S A. 2019; 116(25): 12410-5. PubMed Abstract | Publisher Full Text | Free Full Text

105. Khan O, Giles JR, McDonald S, et al:: TOX transcriptionally and epigenetically programs CD8 ${ }^{+}$T cell exhaustion. Nature. 2019; 571(7764): 211-8.

PubMed Abstract | Publisher Full Text | Free Full Text | Faculty Opinions Recommendation

106. Scott $A C$, Dündar $F$, Zumbo $P$, et al.: TOX is a critical regulator of tumour-specific T cell differentiation. Nature. 2019; 571(7764): 270-4. PubMed Abstract | Publisher Full Text | Free Full Tex

107. Alfei F, Kanev K, Hofmann M, et al:: TOX reinforces the phenotype and longevity of exhausted T cells in chronic viral infection. Nature. 2019; 571(7764): 265-9.

PubMed Abstract | Publisher Full Text | Faculty Opinions Recommendation

108. Yao C, Sun Hw, Lacey NE, et al.: Single-cell RNA-seq reveals TOX as a key regulator of $\mathrm{CD8}^{+} \mathrm{T}$ cell persistence in chronic infection. Nat Immunol. 2019; 20(7): 890-901. PubMed Abstract | Publisher Full Text | Free Full Text

109. Xu W, Zhao X, Wang X, et al:: The Transcription Factor Tox2 Drives T Follicular Helper Cell Development via Regulating Chromatin Accessibility. Immunity. 2019; 51(5): 826-839.e5. PubMed Abstract | Publisher Full Text

110. $\mathrm{He}$ X, He X, Dave VP, et al.: The zinc finger transcription factor Th-POK 
regulates CD4 versus CD8 T-cell lineage commitment. Nature. 2005; 433(7028) $826-33$

PubMed Abstract | Publisher Full Text | Faculty Opinions Recommendation

111. S Sun G, Liu X, Mercado P, et al.: The zinc finger protein cKrox directs CD4 lineage differentiation during intrathymic $\mathrm{T}$ cell positive selection. Nat Immunol. 2005; 6(4): 373-81.

PubMed Abstract | Publisher Full Text | Faculty Opinions Recommendation

112. Vacchio MS, Ciucci T, Gao Y, et al.: A Thpok-Directed Transcriptional Circuitry Promotes Bcl6 and Maf Expression to Orchestrate T Follicular Helper Differentiation. Immunity. 2019; 51(3): 465-478.e6.

PubMed Abstract | Publisher Full Text | Free Full Text

113. Chan I: The role of extracellular matrix protein 1 in human skin. Clin Exp Dermatol. 2004; 29(1): 52-6.

PubMed Abstract | Publisher Full Text

114. Li Z, Zhang Y, Liu Z, et al.: ECM1 controls $T_{H} 2$ cell egress from lymph nodes through re-expression of S1P(1). Nat Immunol. 2011; 12(2): 178-85. PubMed Abstract | Publisher Full Text | Faculty Opinions Recommendation

115. Su P, Chen S, Zheng YH, et al.: Novel Function of Extracellular Matrix Protein 1 in Suppressing Th17 Cell Development in Experimental Autoimmune Encephalomyelitis. J Immunol. 2016; 197(4): 1054-64. PubMed Abstract | Publisher Full Text | Free Full Text

116. He L, Gu W, Wang M, et al.: Extracellular matrix protein 1 promotes follicular helper T cell differentiation and antibody production. Proc Natl Acad Sci U S A 2018; 115(34): 8621-6.

PubMed Abstract | Publisher Full Text | Free Full Text

117. Navarro MN, Feijoo-Carnero C, Arandilla AG, et al:: Protein kinase D2 is a digital amplifier of $T$ cell receptor-stimulated diacylglycerol signaling in naïve CD8 ${ }^{+}$T cells. Sci Signal. 2014; 7(348): ra99. PubMed Abstract | Publisher Full Text | Free Full Text | Faculty Opinions Recommendation

118. Misawa T, SoRelle JA, Choi JH, et al.: Mutual inhibition between Prkd2 and Bcl6 controls T follicular helper cell differentiation. Sci Immunol. 2020; 5(43): eaaz0085.

PubMed Abstract | Publisher Full Text | Free Full Text

119. Crotty S, Kersh EN, Cannons J, et al.: SAP is required for generating long-term humoral immunity. Nature. 2003; 421(6920): 282-7. PubMed Abstract | Publisher Full Text | Faculty Opinions Recommendation

120. C Qi H, Cannons JL, Klauschen F, et al:: SAP-controlled T-B cell interactions underlie germinal centre formation. Nature. 2008; 455(7214): 764-9. PubMed Abstract | Publisher Full Text | Free Full Text | Faculty Opinions Recommendation

121. Preite S, Cannons JL, Radtke AJ, et al:: Hyperactivated PI3K $\boldsymbol{\delta}$ promotes self and commensal reactivity at the expense of optimal humoral immunity. Nat Immunol. 2018; 19(9): 986-1000.

PubMed Abstract | Publisher Full Text | Free Full Text | Faculty Opinions Recommendation

122. Zeng H, Cohen S, Guy C, et al:: mTORC1 and mTORC2 Kinase Signaling and Glucose Metabolism Drive Follicular Helper T Cell Differentiation. Immunity. 2016; 45(3): 540-54.

PubMed Abstract | Publisher Full Text | Free Full Text

123. Shi J, Hou S, Fang Q, et al.: PD-1 Controls Follicular T Helper Cell Positioning and Function. Immunity. 2018; 49(2): 264-274.e4 PubMed Abstract | Publisher Full Text | Free Full Text | Faculty Opinions Recommendation

124. Lu P, Shih C, Qi H: Ephrin B1-mediated repulsion and signaling control germinal center T cell territoriality and function. Science. 2017; 356(6339): eaai9264.

PubMed Abstract | Publisher Full Text

125. Yan H, Wu L, Shih C, et al:: Plexin B2 and Semaphorin 4C Guide T Cell Recruitment and Function in the Germinal Center. Cell Rep. 2017; 19(5): 995-1007.

PubMed Abstract | Publisher Full Text

126. Schrock DC, Leddon SA, Hughson A, et al.: Pivotal role for $\alpha_{v}$ integrins in sustained Th support of the germinal center response for long-lived plasma cell generation. Proc Natl Acad Sci U S A. 2019; 116(10): 4462-70. PubMed Abstract | Publisher Full Text | Free Full Text

127. Weisel FJ, Zuccarino-Catania GV, Chikina M, et al.: A Temporal Switch in the Germinal Center Determines Differential Output of Memory B and Plasma Cells. Immunity. 2016; 44(1): 116-30. PubMed Abstract | Publisher Full Text | Free Full Text | Faculty Opinions Recommendation

128. Maclver NJ, Michalek RD, Rathmell JC: Metabolic regulation of T lymphocytes. Annu Rev Immunol. 2013; 31: 259-83. PubMed Abstract | Publisher Full Text | Free Full Text

129. Buck MD, O'Sullivan D, Pearce EL: T cell metabolism drives immunity. J Exp Med. 2015; 212(9): 1345-60.

PubMed Abstract | Publisher Full Text | Free Full Text |

Faculty Opinions Recommendation
130. Laplante $M$, Sabatini DM: mTOR signaling in growth control and disease. Cell. 2012; 149(2): 274-93.

PubMed Abstract | Publisher Full Text | Free Full Text

131. Chi $\mathrm{H}$ : Regulation and function of $\mathbf{m T O R}$ signalling in $\mathrm{T}$ cell fate decisions. Nat Rev Immunol. 2012; 12(5): 325-38.

PubMed Abstract | Publisher Full Text | Free Full Text

132. Ray JP, Staron MM, Shyer JA, et al:: The Interleukin-2-mTORc1 Kinase Axis Defines the Signaling, Differentiation, and Metabolism of T Helper 1 and Follicular B Helper T Cells. Immunity. 2015; 43(4): 690-702. PubMed Abstract | Publisher Full Text | Free Full Text

133. Hao Y, Wang $Y$, Liu X, et al.: The Kinase Complex mTOR Complex 2 Promotes the Follicular Migration and Functional Maturation of Differentiated Follicular Helper CD4+ T Cells During Viral Infection. Front Immunol. 2018; 9: 1127. PubMed Abstract | Publisher Full Text | Free Full Text

134. Kitano M, Moriyama S, Ando Y, et al:: Bcl6 protein expression shapes pregerminal center B cell dynamics and follicular helper T cell heterogeneity. Immunity. 2011; 34(6): 961-72.

PubMed Abstract | Publisher Full Text | Faculty Opinions Recommendation

135. Lüthje K, Kallies A, Shimohakamada Y, et al.: The development and fate of follicular helper T cells defined by an IL-21 reporter mouse. Nat Immunol. 2012; 13(5): 491-8.

PubMed Abstract | Publisher Full Text | Faculty Opinions Recommendation

136. Shulman Z, Gitlin AD, Targ S, et al.: T follicular helper cell dynamics in germinal centers. Science. 2013; 341(6146): 673-7. PubMed Abstract | Publisher Full Text | Free Full Text | Faculty Opinions Recommendation

137. Oestreich KJ, Read KA, Gilbertson SE, et al.: Bcl-6 directly represses the gene program of the glycolysis pathway. Nat Immunol. 2014; 15(10): 957-64. PubMed Abstract | Publisher Full Text | Free Full Text

138. Yi W, Gupta S, Ricker E, et al.: The mTORC1-4E-BP-elF4E axis controls de novo Bcl6 protein synthesis in T cells and systemic autoimmunity. Nat Commun. 2017; 8(1): 254

PubMed Abstract | Publisher Full Text | Free Full Text

139. Cho SH, Raybuck AL, Stengel K, et al:: Germinal centre hypoxia and regulation of antibody qualities by a hypoxia response system. Nature. 2016; $\mathbf{5 3 7 ( 7 6 1 9 ) : ~}$ 234-8.

PubMed Abstract | Publisher Full Text | Free Full Text

140. Cho SH, Raybuck AL, Blagih J, et al.: Hypoxia-inducible factors in CD4+ T cells promote metabolism, switch cytokine secretion, and $\mathrm{T}$ cell help in humoral immunity. Proc Natl Acad Sci U S A. 2019; 116(18): 8975-84. PubMed Abstract | Publisher Full Text | Free Full Text

141. Sitkovsky M, Ohta A: Targeting the hypoxia-adenosinergic signaling pathway to improve the adoptive immunotherapy of cancer. J Mol Med (Berl). 2013; 91(2): 147-55.

PubMed Abstract | Publisher Full Text | Free Full Text

142. Abbott RK, Silva M, Labuda J, et al.: The GS Protein-coupled A2a Adenosine Receptor Controls T Cell Help in the Germinal Center. J Biol Chem. 2017; 292(4): 1211-7.

PubMed Abstract | Publisher Full Text | Free Full Text

143. Alam MS, Costales MG, Cavanaugh C, et al:: Extracellular adenosine generation in the regulation of pro-inflammatory responses and pathogen colonization. Biomolecules. 2015; 5(2): 775-92.

PubMed Abstract | Publisher Full Text | Free Full Text

144. Proietti M, Cornacchione V, Rezzonico Jost T, et al:: ATP-gated ionotropic P2X7 receptor controls follicular T helper cell numbers in Peyer's patches to promote host-microbiota mutualism. Immunity. 2014; 41(5): 789-801. PubMed Abstract | Publisher Full Text

145. Victora GD, Nussenzweig MC: Germinal centers. Annu Rev Immunol. 2012; 30 429-57. PubMed Abstract | Publisher Full Text

146. Victora GD, Schwickert TA, Fooksman DR, et al.: Germinal center dynamics revealed by multiphoton microscopy with a photoactivatable fluorescent reporter. Cell. 2010; 143(4): 592-605.

PubMed Abstract | Publisher Full Text | Free Full Text | Faculty Opinions Recommendation

147. Le TvL, Kim TH, Chaplin DD: Intraclonal competition inhibits the formation of high-affinity antibody-secreting cells. J Immunol. 2008; 181(9): 6027-37. PubMed Abstract | Publisher Full Text | Free Full Text

148. Awe O, Hufford MM, Wu H, et al:: PU.1 Expression in T Follicular Helper Cells Limits CD40L-Dependent Germinal Center B Cell Development. J Immunol. 2015; 195(8): 3705-15. PubMed Abstract | Publisher Full Text | Free Full Text

149. Meli AP, Fontés G, Avery DT, et al:: The Integrin LFA-1 Controls T Follicular Helper Cell Generation and Maintenance. Immunity. 2016; 45(4): 831-46. PubMed Abstract | Publisher Full Text | Free Full Text

150. Cao $Y$, Yang $Q$, Deng $H$, et al.: Transcriptional factor ATF3 protects against colitis by regulating follicular helper T cells in Peyer's patches. Proc Natl Acad Sci U S A. 2019; 116(13): 6286-91. PubMed Abstract | Publisher Full Text | Free Full Text

151. Zotos D, Coquet JM, Zhang Y, et al:: IL-21 regulates germinal center B cell 
differentiation and proliferation through a B cell-intrinsic mechanism. $J$ Exp Med. 2010; 207(2): 365-78.

PubMed Abstract | Publisher Full Text | Free Full Text |

Faculty Opinions Recommendation

152. Dinterman MA, Beaton L, Di Yu, et al.: IL-21 acts directly on B cells to regulate $\mathrm{Bcl}-6$ expression and germinal center responses. J Exp Med. 2010; 207(2): 353-63.

PubMed Abstract | Publisher Full Text | Free Full Text |

Faculty Opinions Recommendation

153. Reinhardt RL, Liang HE, Locksley RM: Cytokine-secreting follicular T cells shape the antibody repertoire. Nat Immunol. 2009; 10(4): 385-93. PubMed Abstract | Publisher Full Text | Free Full Text

154. King IL, Mohrs M: IL-4-producing $\mathrm{CD}^{+} \mathrm{T}$ cells in reactive lymph nodes during helminth infection are T follicular helper cells. J Exp Med. 2009; 206(5): $1001-7$.

PubMed Abstract | Publisher Full Text | Free Full Text | Faculty Opinions Recommendation

155. Clatman Zaretsky A, Taylor JJ, King IL, et al.: T follicular helper cells differentiate from Th2 cells in response to helminth antigens. J Exp Med. 2009; 206(5): 991-9.

PubMed Abstract | Publisher Full Text | Free Full Text | Faculty Opinions Recommendation

156. Weinstein JS, Herman El, Lainez B, et al.: TFH cells progressively differentiate to regulate the germinal center response. Nat Immunol. 2016; 17(10): 1197-1205

PubMed Abstract | Publisher Full Text | Free Full Text |

Faculty Opinions Recommendation

157. Gowthaman U, Chen JS, Zhang B, et al:: Identification of a T follicular helper cell subset that drives anaphylactic IgE. Science. 2019; 365(6456): eaaw6433. PubMed Abstract | Publisher Full Text | Free Full Text | Faculty Opinions Recommendation

158. Yusuf I, Kageyama R, Monticelli L, et al:: Germinal center T follicular helper cell IL-4 production is dependent on signaling lymphocytic activation molecule receptor (CD150). J Immunol. 2010; 185(1): 190-202. PubMed Abstract | Publisher Full Text | Free Full Text

159. Zheng WP, Flavell RA: The Transcription Factor GATA-3 Is Necessary and Sufficient for Th2 Cytokine Gene Expression in CD4 T Cells. Cell. 1997; 89(4): 587-96.

PubMed Abstract | Publisher Full Text

160. Clement RL, Daccache J, Mohammed MT, et al:: Follicular regulatory T cells control humoral and allergic immunity by restraining early $B$ cell responses. Nat Immunol. 2019; 20(10): 1360-71.

PubMed Abstract | Publisher Full Text | Free Full Text | Faculty Opinions Recommendation

161. Liang $\mathrm{H}$, Tang J, Liu Z, et al:: ZIKV infection induces robust Th1-like Tfh cell and long-term protective antibody responses in immunocompetent mice. Nat Commun. 2019; 10(1): 3859.

PubMed Abstract | Publisher Full Text | Free Full Text
162. Weinstein JS, Laidlaw BJ, Lu Y, et al.: STAT4 and T-bet control follicular helper T cell development in viral infections. J Exp Med. 2018; 215(1): 337-55. PubMed Abstract | Publisher Full Text | Free Full Text

163. Sheikh AA, Cooper L, Feng M, et al:: Context-Dependent Role for T-bet in T Follicular Helper Differentiation and Germinal Center Function following Viral Infection. Cell Rep. 2019; 28(7): 1758-1772.e4. PubMed Abstract | Publisher Full Text | Free Full Text

164. Wang $P$, Wang $Y, X i e ~ L$, et al:: The Transcription Factor T-Bet Is Required for Optimal Type I Follicular Helper T Cell Maintenance During Acute Viral Infection. Front Immunol. 2019; 10: 606.

PubMed Abstract | Publisher Full Text | Free Full Text

165. Elsner RA, Shlomchik MJ: IL-12 Blocks Tfh Cell Differentiation during Salmonella Infection, thereby Contributing to Germinal Center Suppression. Cell Rep. 2019; 29(9): 2796-2809.e5. PubMed Abstract | Publisher Full Text | Free Full Text

166. Fang $\mathrm{D}, \mathrm{Cui} \mathrm{K}, \mathrm{Mao} \mathrm{K}$, et al:: Transient T-bet expression functionally specifies a distinct T follicular helper subset. J Exp Med. 2018; 215(11): 2705-14. PubMed Abstract | Publisher Full Text | Free Full Text

167. Papillion A, Powell MD, Chisolm DA, et al:: Inhibition of IL-2 responsiveness by IL-6 is required for the generation of GC-TFH cells. Sci Immunol. 2019; 4(39): eaaw7636.

PubMed Abstract | Publisher Full Text | Free Full Text | Faculty Opinions Recommendation

168. Fazilleau N, Eisenbraun MD, Malherbe L, et al.: Lymphoid reservoirs of antigenspecific memory T helper cells. Nat Immunol. 2007; 8(7): 753-61. PubMed Abstract | Publisher Full Text

169

Hale JS, Youngblood B, Latner DR, et al.: Distinct memory CD4+ $\mathrm{T}$ cells with commitment to $\mathrm{T}$ follicular helper- and $\mathrm{T}$ helper 1-cell lineages are generated after acute viral infection. Immunity. 2013; 38(4): 805-17. PubMed Abstract | Publisher Full Text | Free Full Text | Faculty Opinions Recommendation

170. Asrir A, Aloulou M, Gador M, et al.: Interconnected subsets of memory follicula helper T cells have different effector functions. Nat Commun. 2017; 8(1): 847. PubMed Abstract | Publisher Full Text | Free Full Text

171. Ciucci T, Vacchio MS, Gao Y, et al.: The Emergence and Functional Fitness of Memory $\mathrm{CD}^{+} \mathrm{T}$ Cells Require the Transcription Factor Thpok. Immunity. 2019; 50(1): 91-105.e4. PubMed Abstract | Publisher Full Text | Free Full Text | Faculty Opinions Recommendation

172. Künzli M, Schreiner D, Pereboom TC, et al.: Long-lived T follicular helper cells retain plasticity and help sustain humoral immunity. Sci Immunol. 2020; 5(45): eaay5552.

PubMed Abstract | Publisher Full Text

173. Cirelli KM, Carnathan DG, Nogal B, et al: Slow Delivery Immunization Enhances HIV Neutralizing Antibody and Germinal Center Responses via Modulation of Immunodominance. Cell. 2019; 177(5): 1153-1171.e28 PubMed Abstract | Publisher Full Text | Free Full Text | Faculty Opinions Recommendation 